\title{
NORFACE
}

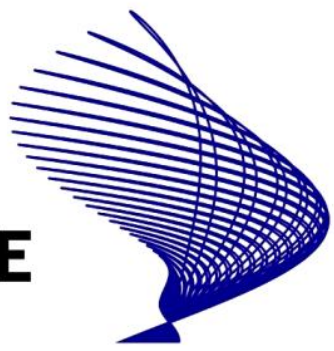

NORFACE MIGRATION Discussion Paper No. 2011-19

\section{Immigrant Wage Profiles Within and Between Establishments}

Erling Barth, Bernt Bratsberg and Oddbjørn Raaum 
October 2011

\title{
Immigrant Wage Profiles Within and Between Establishments
}

\author{
Erling Barth \\ Institute for Social Research, Oslo \\ Bernt Bratsberg \\ Ragnar Frisch Centre for Economic Research \\ Oddbjørn Raaum \\ Ragnar Frisch Centre for Economic Research
}

\begin{abstract}
Life cycle wages of immigrants from developing countries fall short of catching up with wages of natives. This disparity reflects both lower wages at entry and lower wage growth. Using linked employer-employee data, we show that 40 percent of the native-immigrant wage gap is explained by differential sorting across establishments. Our findings point to differences in job mobility and intermittent spells of unemployment as major sources of the discrepancy in lifetime wages. The inferior wage growth of immigrants primarily results from failure to advance to higher paying establishments over time. This pattern is consistent with statistical discrimination in hiring but not with monopsonistic discrimination due to informational frictions.
\end{abstract}

\footnotetext{
*We are grateful for helpful comments from seminar and conference participants at CReAM, UCL (September 2010), IFAU (October 2010), and EALE (2011). We also gratefully acknowledge funding from the Norwegian Research Council (grant \#173599/S20) and NORFACE (grant \#415). This paper is part of the research activities of the centre of Equality, Social Organization, and Performance, University of Oslo. Data made available by Statistics Norway have been essential for this research.
} 


\section{Introduction}

Recent studies show that segregation of immigrants and natives across firms contributes significantly to the immigrant-native wage gap. ${ }^{1}$ Immigrants from developing countries are more likely than natives to work in low-paying firms. This observation raises two important questions: What is the contribution of job mobility versus within-job wage increases to the overall wage growth for immigrants, and how do these two sources of wage growth compare for immigrants and natives? The answers to these questions will improve our understanding of the potential hurdles immigrants face in the labor market and provide insights into the economic assimilation process of immigrants.

This paper examines the implications of sorting by ethnicity across firms ${ }^{2}$ over time by means of an extended assimilation regression framework, using employer-employee data from Norway. We focus on immigrants from developing countries, as immigrants from highincome source countries typically have earnings close to those of natives with similar education and experience (Barth et al., 2004). While the empirical wage assimilation literature has examined the role of occupational transitions (Weiss et al., 2003; Eckstein and Weiss, 2004), the importance of job mobility and the distribution of workers across firms over the life cycle remain largely unexplored. When equally productive workers receive unequal pay in different firms (Groshen, 1991; Abowd et al., 1999), for example due to rent sharing (Card et al., 2010), differential access to high-pay firms will generate wage gaps between groups.

Job-to-job transitions are important sources of wage growth, particularly during the first 10-15 years in the labor market (see, e.g., Topel and Ward, 1992). We separate wage growth occurring as a result of seniority with the same employer from that arising from job mobility. We use the firm fixed effects estimator to identify pay growth within establishments, and track the development of establishment wage effects over time to tease out the part of wage growth that follows from job change. Aydemir and Skuterud (2008) find workplace sorting to be a more important source of male immigrant-native wage differentials than differences in pay within establishments. The authors also report evidence that workplace sorting plays a role in immigrant wage assimilation, as, at least for male

\footnotetext{
${ }^{1}$ See Aydemir and Skuterud (2008) and Pendakur and Woodcock (2010).

${ }^{2}$ In our data, the employer unit is the establishment but we will use firm and establishment interchangeably in the text.
} 
immigrants from developing countries, older immigrants have jobs in better-paying establishments than recent immigrants. But because their evidence comes from comparing recent and non-recent immigrants in cross-sectional data, the authors are unable to separate assimilation effects from cohort differences in establishment affiliation. In the present study, we draw on data covering a 10-year period, which allows us to separate assimilation and cohort effects (see, e.g., the discussion of assimilation vs. cohort effects on immigrant earnings in Borjas, 1995). In our empirical model, wages are determined by experience, or years since migration for immigrants, as well as educational attainment, accounting for immigrant cohort heterogeneity and the allocation of workers across firms.

Separating wage growth between and within firms, our empirical analysis sheds light on the relative importance of two types of mechanisms that might hamper immigrant wage progress. The first mechanism is statistical discrimination based on lack of information on part of employers, while the second is monopsonistic discrimination due to limited information on part of employees. ${ }^{3}$

In a search framework, gains from job mobility depend on opportunities for new jobs in terms of job arrival rates and wages, as well as the frequency of job destruction (separations). First, statistical discrimination may limit the arrival rate of favorable job offers because, at the stage of hiring, employers are less precisely informed about the productivity of immigrant applicants compared to natives. Such information asymmetries and even selffulfilling expectations would imply that immigrants reap smaller gains from job mobility than natives, while their within-firm wage profile should be steeper as the current employer gains information about true worker productivity (see, e.g., Oettinger, 1996; Farmer and Terrell, 1996). Consistent with these predictions, Bratsberg and Terrell (1998) document that young black men in the United States earn lower returns to general experience but at least as high returns to firm-specific seniority as do young white men. If statistical discrimination were important, we would expect wage growth of immigrants primarily to take place within firms. As employers have little incentive to reveal their knowledge to other firms, immigrants will have smaller expected gains from wage increments related to job mobility.

\footnotetext{
${ }^{3}$ An example of how monopsonistic discrimination may prevail in the labor market is given by Bowlus and Eckstein (2002), who consider a situation where some employers have discriminatory tastes. Barth and DaleOlsen (2009) develop a model of monopsonistic discrimination to explain the gender wage gap.
} 
Secondly, wage gains from job change depend on the nature of the separation. An involuntary job shift is likely to lead to a less favorable new job than a voluntary move, simply because the floor provided by the current wage disappears when the separation is involuntary. Group differences in gains from mobility will thus depend on the relative intensity of job losses and job options. The negative effect of limited outside options will be amplified in a situation where immigrants face a higher probability of job loss than native workers. Examples of mechanisms that could provide exactly such a situation are employment under "last in, first out" (LIFO) rules and immigrants being more likely to take on high-risk jobs in the first place. The combination of statistical discrimination, LIFO, and uncertain jobs may create a regime where immigrants are trapped in bad jobs.

An alternative candidate for explaining differential wage growth between natives and immigrants is monopsonistic discrimination arising from informational frictions. When immigrants are less informed about outside job opportunities, there is less need for employers to give pay raises to avoid turnover. However, this informational disadvantage is likely to fade over time following improvements in language proficiency, extended social networks, and accumulation of cultural knowledge. In this case, wage assimilation arises as a result of immigrants catching up with natives in terms of information about jobs, and we would expect relative immigrant wage growth to primarily occur between rather than within jobs. ${ }^{4}$

Consequently, empirical evidence on immigrants' wage growth between jobs relative to that of native workers can be used to sort out the relevance of statistical discrimination versus informational disadvantage of newcomers. Implications for within-job wage growth are, on the other hand, less clear-cut. The reason is that the existence of statistical discrimination may provide incentives for monopsonistic discrimination as well: Even if the current employer over time gains additional information about the productivity of their own workers, workers may not be able to cash in on the improved perceptions simply because the outside option lags behind. In the case of statistical discrimination, within-firm wage growth

\footnotetext{
${ }^{4}$ Many job matches are facilitated by information from family, friends, or colleagues. Some studies indicate that social networks are particularly important for ethnic minorities, see, e.g., the discussion in Patacchini and Zenou (2008). Thus, smaller and less favorable networks may account for lower hiring rates among ethnic minorities (Reingold, 1999) even if the evidence is mixed. In a study that "delineates the various mechanisms by which minorities can be isolated from good job opportunities," Fernandez and Fernandez-Mateo (2006) find only scant evidence that network factors serve to limit employment opportunities of minorities.
} 
is subject to two countervailing forces: increased information works towards a steeper wage profile, whereas lack of information on part of other employers will tend to keep wages low.

\section{Immigrant wage assimilation with firm effects and job mobility}

The standard economic assimilation study is based on a regression framework where, in one formulation, the log wage equation for immigrants is

$$
\ln w_{i t}=\alpha^{I}+Z_{i t} \beta^{I}+g\left(X_{i t}\right)+h\left(A_{0 i}\right)+c_{i}^{I}+\pi_{t}^{I}+u_{i t}^{I},
$$

where the log wage of immigrant worker $i$ in year $t$ depends on potential experience in the host country labor market or years since arrival $(X)$, and age at the time of arrival $\left(A_{0}\right) .{ }^{5}$ In equation (1), $c$ is a vector of arrival cohort effects, $\pi$ a vector of period effects, $u$ denotes other factors, and $Z$ captures covariates like educational attainment and the local unemployment rate. The log wage equation for native workers is

$$
\ln w_{i t}=\alpha^{N}+Z_{i t} \beta^{N}+k\left(X_{i t}\right)+c_{i}^{N}+\pi_{t}^{N}+u_{i t}^{N},
$$

where $X$ again denotes potential experience (or years since leaving school, defined as age-6the statutory years of schooling for the individual's attainment), and $Z$ represents other observed individual characteristics. Note that, because calendar year equals the sum of year of arrival and years since arrival, some restriction, such as the "equal period effect" assumption $\left(\pi_{t}^{I}=\pi_{t}^{N}\right)$, is necessary for identification of immigrant wage profiles and cohort effects (Borjas, 1995). We also include cohort effects for natives motivated by long-run effects of macroeconomic entry conditions or cohort size (Welch, 1979; Raaum and Røed, 2006). To avoid perfect collinearity between cohort, age, and observation year, identification is based on the assumption that native cohort effects are equal within five-year intervals. For

\footnotetext{
${ }^{5}$ Note that our model specification and notation differ somewhat from Borjas (1999) as we use "years since arrival" and "age at immigration," rather than the more conventional "years since arrival" and "age," in the set up. With controls for immigrant cohort, the two approaches are equivalent, even though the coefficient of the "year since arrival" term will represent different underlying parameters in the two formulations. Specifically, our $g(X)$-function captures what Borjas (p. 1719) denotes $\left(\delta_{\mathrm{i}}+\alpha\right)$, the sum of wage effects of aging and years since migration.
} 
individual characteristics we distinguish between three educational groups, and the model is estimated based on the pooled samples with full sets of interaction terms for immigrants and natives, except for arrival cohort effects which are set common to immigrants with different education levels, and equal calendar year effects for natives and immigrants. ${ }^{6}$

Prior studies document earnings assimilation among immigrants during the first 10-15 years of residency in Norway, e.g., Barth et al. (2004), and one of the empirical questions we address in the present paper is whether a similar pattern exists for hourly wages.

\subsection{Firm wage effects}

In our empirical analysis, we expand the wage residuals of equations (1) and (2) by introducing a firm-specific wage component $\left(\varphi_{f}\right)$ common to all workers in the firm

$$
u_{i t}^{j}=\varphi_{f}+\varepsilon_{i t}^{j}, j=I, N
$$

The 'within-firm' wage profiles of immigrant and native workers, estimated conditional on the firm fixed effect, will differ from the unconditional wage profiles if workers move to firms with a higher wage component over time. During the early years of the job career, search and job shopping are factors that are expected to lead to job mobility with positive wage gains. Job mobility caused by displacement or elapsed contracts are, on the other hand, less likely to involve wage gains. Our focus is whether and how the association between firm-fixed wage effects and (post-education) host-country experience differs between immigrants and natives. Different mobility patterns both in terms of job change rates and wage gains will give rise to differences in experience profiles by nativity.

Matched employer-employee data with several worker records per firm are needed to estimate the firm fixed effect. In our empirical analysis, we rely on repeated cross-sectional data that allow for identification of firm fixed effects, but have limitations when it comes to accounting for unobserved individual worker heterogeneity. Thus, sorting on unobserved individual characteristics may bias our estimates of the firm fixed effect, for instance in the case of assortative matching (see, e.g., Abowd et al., 1999, and Shimer, 2005). Abowd et al. (2003) present evidence, however, that wage heterogeneity across firms, as reflected in the

\footnotetext{
${ }^{6}$ Note however that the empirical model allows for differential effects of local labor market conditions by immigrant status, which relaxes the equal period effects assumption relative to the standard setup (see Bratsberg et al., 2006).
} 
firm size effect on wages, is driven almost entirely by firm heterogeneity, and only very modestly by assortative matching of workers and firms. Abowd et al. (2009) furthermore show that the correlations between firm and individual fixed effects in their log wage regressions are "generally small in absolute value, ranging between about -0.20 and 0.25 " ( $p$. 7), indicating that sorting on unobserved individual characteristics might be a minor concern. We therefore proceed with interpreting our estimated firm fixed effects as primarily reflecting true workplace heterogeneity, even though ideally a two-way fixed effects model would have been preferable.

\subsection{Sources of work experience}

Post-education experience differs for immigrants and natives as immigrants bring some of their labor market experience from abroad. Compared to natives, we would expect adult immigrants from developing countries to possess less relevant work experience due to generally high unemployment rates in their home country, time spent on the migration process, and, perhaps, their experiences as refugees. Moreover, the economic returns to any pre-migration work experience might be expected to be low because of different types of work and any qualifications obtained will, on average, be of limited value to employers in the host country (Friedberg, 2000). Comparing individuals of similar age and educational attainment, we would expect lower wages among immigrants because they have accumulated less relevant work experience and lack host-country specific skills. In our empirical model, the wage effects of foreign and host-country experience are assumed to be additive. Foreign work experience is captured by the "age at immigration" term and the $g(X)$-function will measure the returns to experience since migration.

As immigrants spend time in the host country, they acquire competencies and qualifications from both work and leisure activities. One might expect that the broad part of immigrant labor market integration takes place through work. Time spent at work will involve accumulation of work-related skills, language competence through social interaction with native co-workers, on-the-job training activities, and so on. ${ }^{7}$ To check for the importance of actual (versus potential) work experience, we construct for each individual a

\footnotetext{
${ }^{7}$ This perspective is parallel to one explanation for the gender wage gap where women are penalized for years out of the labor force, see, e.g., Manning and Swaffield (2008).
} 
measure of cumulative years with employment since the date of arrival. ${ }^{8}$ Our simple test is to include cumulative years out of employment as a control variable in the empirical model, allowing for separate coefficients for natives and immigrants within educational groups.

\subsection{Seniority profiles and returns to job change}

Workers accumulate firm-specific qualifications as well as general human capital on the job. When workers are rewarded from staying with the same employer over time, whether because of returns to accumulation of firm-specific human capital (Becker, 1975) or from some type of deferred payment scheme (Lazear, 1981), native-immigrant wage differentials will arise if immigrants accumulate less firm-specific experience than natives (McDonald and Worswick, 1998), for example due to layoff selection based on "last in-first out" principles. If immigrants are less efficient in signaling their productivity, or face other types of statistical discrimination, returns to seniority might be higher for immigrants than for natives, as the employer has the advantage of observing individual skills more precisely (Farmer and Terrell, 1996).

A key problem in identifying seniority wage profiles is that workers tend to stay longer at establishments that offer high wages for other reasons. We use the fixed establishment effect estimator that sweeps out time-invariant effects of other workplace attributes (Barth, 1997). As an implicit study of wage gains from job mobility, we analyze how the firm-specific wage component of each worker evolves over time, separately for natives and immigrants. We do this by estimating an auxiliary wage regression where the value of the firm wage effect serves as the dependent variable. In this model, a positive coefficient of experience will reflect returns to job search in terms of employment in better paying firms over time. This effect summarizes, of course, both the probability of job change and the wage gain from job change in a given year. If the estimate of the firm wage effect, as noted above, is influenced by unobserved individual characteristics, some caution is needed when interpreting this coefficient as it may reflect sorting of individuals into firms with highability co-workers as well as into firms with a high pure firm-specific wage premium.

\footnotetext{
${ }^{8}$ Although the dependent variable - the hourly wage - is observed between 1997 and 2006, we are able to match the wage data to individual annual earnings records from 1967 onwards for all workers. We use these records to construct a variable measuring cumulative employment simply defined as years with positive labor earnings.
} 


\section{Data}

Wages. Individual wage records are drawn from the annual Wage Statistics surveys, administered by Statistics Norway in September-October of each year. The data cover all sectors except for the primary industries and they are collected through stratified surveys (with complete coverage of public sector employees. Small establishments with fewer than five employees are not included. All large firms (more than 100-150 employees, depending on industry) are covered, while small (fewer than 25 to 50 employees, depending on industry) and medium sized firms have a sampling rate of 10-40 percent depending on industry. As the sampling of firms is annual, the data do not have a representative longitudinal structure. Firms that are included report wage information for all employees. Sampling weights are based on the inverse inclusion probability and post-stratification with regard to industry and employment at the date of the most recent census. The weights are additionally adjusted for any imbalances due to non-responses. Information is collected on basic paid salaries, fixed and variable additional allowances, bonuses and commissions, overtime pay as well as contractual and overtime working hours. We compute the hourly wage as the ratio of monthly pay_-including variable allowances, bonuses, and commissions, but excluding overtime pay - to contractual hours worked during the survey month.

Immigrant status. Information on immigrant status is drawn from the central population register and is linked to the pay record by means a personal identifier. We exclude from the analysis immigrants from rich developed countries in Europe, North America, and Oceania. These immigrant groups move frequently between countries with high return migration rates (Bratsberg et al., 2007) and have labor market outcomes in line with those of native workers (Barth et al., 2004). Date of admission to Norway is used to define years since arrival and immigrant arrival cohort. Immigrants who arrived in Norway before age 16 are excluded as they experienced part of their childhood in the host country and therefore expected to have a different wage profile than older immigrants. The majority of immigrants in our study are from developing countries, typically with refugee status or family reunification as the basis for residency in Norway. ${ }^{9}$

\footnotetext{
${ }^{9}$ Of the total immigrant flow to Norway from developing countries between 1990 and 2007, only four percent were admitted as labor immigrants, while 57 percent were admitted as refugees and 30 percent as part of a family reunification process (Statistics Norway, 2008).
} 
Educational attainment. The Norwegian educational register contains, in principle, the educational attainment of all individuals living in Norway, based on reporting from domestic schools and universities and the agency that certifies education from abroad ("NOKUT"). As educational qualifications obtained abroad nonetheless often are missing, so is educational information for immigrants. To update the register Statistics Norway administered surveys in 1989 and 1999 to all resident immigrants without registered educational attainments at the time. Finally, the register will include self-reported attainment taken from the censuses of population when education data otherwise is missing. In this study, we include immigrants for whom education is missing in our analyses, but present results only for those with non-missing educational attainment throughout. The three groups are labeled low (less than 13 years of schooling; i.e., not completed the upper secondary level), medium (13-14 years), and high (more than 14 years) education.

Age, gender, and sample period. Samples are restricted to male workers aged 20 to 65 in the observation year; the observation period is 1997 to 2006.

\subsection{Descriptive statistics}

The core descriptive statistics are reported in Table 1. The average native-immigrant wage differential is $0.14 \log$ point for the low educated group and even larger at 0.19 for the medium and $0.21 \log$ point for the high education groups. Wages are increasing in educational attainment for both immigrants and natives, but the unadjusted education wage premium is greater for natives. Mean ages are fairly similar by nativity, except for the low education group where natives are much older (reflecting rising levels of education across native birth cohorts). For immigrants, age at entry is increasing in educational attainment, with group means ranging from 27 to 30 years of age. Within education group, there is hardly any difference in average attainment for immigrant and native workers in our sample.

The average years since entry for immigrants is close to 13 years in each of the three education groups. Eastern Europeans constitute almost one quarter of the immigrant observations with Bosnia the major source country. Employees from Iran and Iraq are the largest country groups from the Northern Africa and Middle East region. Other Asia is the largest source region (31 percent of all immigrant observations), with Sri Lanka the main source country ( 9.8 percent of immigrant observations). Developing country immigrants are 
definitely a minority in the Wage Statistics survey data, slightly overrepresented among workers with low education, and with shares between 2.0 and 3.6 percent of the sample. Immigrants are much more likely than natives to have immigrant co-workers; the average immigrant share of the establishment is about 2 percent for native workers and ranges from 25 percent for high-education to 34 percent for low-education immigrant workers.

Table 1. Sample means.

\begin{tabular}{|c|c|c|c|c|c|c|c|}
\hline \multirow[b]{2}{*}{ Variable } & \multicolumn{2}{|c|}{ Low education } & \multicolumn{2}{|c|}{ Medium education } & \multicolumn{2}{|c|}{ High education } & \multirow{2}{*}{$\begin{array}{l}\text { Educ } \\
\text { missing }\end{array}$} \\
\hline & $\mathrm{Imm}$ & Native & $\mathrm{Imm}$ & Native & $\mathrm{Imm}$ & Native & \\
\hline Log hourly wage & 4.81 & 4.95 & 4.87 & 5.06 & 5.04 & 5.25 & 4.85 \\
\hline Age & 39.2 & 44.7 & 40.8 & 39.1 & 43.0 & 41.7 & 34.8 \\
\hline Age at entry & 26.7 & & 28.0 & & 30.1 & & 29.5 \\
\hline Years since entry & 12.5 & & 12.8 & & 12.9 & & 5.4 \\
\hline Years schooling & 10.4 & 10.6 & 13.3 & 13.2 & 17.2 & 17.1 & \\
\hline Log local unempl & -3.72 & -3.80 & -3.74 & -3.78 & -3.73 & -3.77 & -3.69 \\
\hline $\begin{array}{l}\text { Establishment } \\
\text { immigrant share } \\
\text { Origin: }\end{array}$ & .343 & .024 & .272 & .019 & .246 & .020 & .427 \\
\hline Balkans & .172 & & .238 & & .119 & & .167 \\
\hline Bosnia & .083 & & .132 & & .057 & & .056 \\
\hline Other East Europe & .034 & & .052 & & .133 & & .129 \\
\hline Poland & .013 & & .026 & & .064 & & .071 \\
\hline N.Africa/M.East & .212 & & .199 & & .249 & & .290 \\
\hline Iran & .036 & & .075 & & .115 & & .022 \\
\hline Iraq & .054 & & .038 & & .045 & & .123 \\
\hline Other Africa & .115 & & .125 & & .148 & & 107 \\
\hline Somalia & .040 & & .027 & & .018 & & .040 \\
\hline Other Asia & .403 & & .281 & & .259 & & .254 \\
\hline Sri Lanka & .138 & & .106 & & .057 & & .084 \\
\hline Vietnam & .113 & & .062 & & .031 & & .017 \\
\hline South America & .063 & & .103 & & .092 & & .054 \\
\hline Chile & .046 & & .080 & & .055 & & .025 \\
\hline Observations & 49248 & 1311056 & 42105 & 1968568 & 29974 & 1489626 & 28082 \\
\hline $\begin{array}{l}\text { Immigrant sample } \\
\text { share }\end{array}$ & \multicolumn{2}{|c|}{.036} & \multicolumn{2}{|c|}{.021} & \multicolumn{2}{|c|}{.020} & 1 \\
\hline
\end{tabular}

Note: Sample means are weighted using year-by-establishment sampling weights. There are a total of 90,189 establishments in the sample. 


\section{Results}

The basic immigrant-native wage differentials over the sample period, conditional on educational attainment and controlling for calendar year of observation only, are presented in Table 2. As the first table entry shows, wages of low-educated immigrants from developing countries are on average $0.164 \log$ point below native workers with similar educational attainment. When we split the immigrant sample by years since migration (YSM), we find that the wage gap is greater for recent $(\mathrm{YSM}<10)$ than for non-recent immigrants, consistent with the proposition that immigrant accumulation of human capital with time in the new country results in wage assimilation.

Table 2. Immigrant-native wage differentials.

\begin{tabular}{|c|c|c|c|c|c|c|}
\hline & \multicolumn{2}{|c|}{ Low education } & \multicolumn{2}{|c|}{ Medium education } & \multicolumn{2}{|c|}{ High education } \\
\hline & (1) & (2) & (3) & (4) & (5) & (6) \\
\hline Immigrant & $\begin{array}{l}-0.164 \\
(0.001)\end{array}$ & $\begin{array}{c}-0.093 \\
(0.001)\end{array}$ & $\begin{array}{l}-0.196 \\
(0.002)\end{array}$ & $\begin{array}{l}-0.110 \\
(0.001)\end{array}$ & $\begin{array}{l}-0.219 \\
(0.003)\end{array}$ & $\begin{array}{l}-0.133 \\
(0.002)\end{array}$ \\
\hline $\begin{array}{l}\text { Recent } \\
(\mathrm{YSM}<10)\end{array}$ & $\begin{array}{l}-0.207 \\
(0.002)\end{array}$ & $\begin{array}{l}-0.114 \\
(0.002)\end{array}$ & $\begin{array}{l}-0.250 \\
(0.003)\end{array}$ & $\begin{array}{l}-0.141 \\
(0.002)\end{array}$ & $\begin{array}{l}-0.271 \\
(0.005)\end{array}$ & $\begin{array}{l}-0.167 \\
(0.003)\end{array}$ \\
\hline $\begin{array}{l}\text { Non-recent } \\
(\mathrm{YSM}>=10)\end{array}$ & $\begin{array}{l}-0.137 \\
(0.002)\end{array}$ & $\begin{array}{l}-0.080 \\
(0.002)\end{array}$ & $\begin{array}{l}-0.165 \\
(0.002)\end{array}$ & $\begin{array}{l}-0.093 \\
(0.002)\end{array}$ & $\begin{array}{l}-0.191 \\
(0.003)\end{array}$ & $\begin{array}{l}-0.114 \\
(0.002)\end{array}$ \\
\hline $\begin{array}{l}\text { Firm fixed } \\
\text { effects }\end{array}$ & No & Yes & No & Yes & No & Yes \\
\hline $\begin{array}{l}\text { Immigrant obs } \\
\text { Native obs } \\
\text { Controls }\end{array}$ & \multicolumn{2}{|c|}{$\begin{array}{c}49248 \\
1311056\end{array}$} & \multicolumn{2}{|c|}{ Calendar year fixed effec } & \multicolumn{2}{|c|}{1489626} \\
\hline
\end{tabular}

Note: Standard errors are reported in parentheses. Regressions in columns (2), (4), and (6) include 90,189 firm fixed effects.

The estimates with firm fixed effects show less dramatic patterns. When we account for time-invariant firm factors, the native-immigrant wage gap for less educated workers declines from 0.164 to $0.093 \log$ point. For medium and high education workers, the drop is of a similar magnitude. In other words, more than 40 percent of the observed wage differential can be attributed to where immigrants (and natives) work. On average, immigrants work in low-paying firms. 
From an assimilation perspective, it is of interest to read from the table that the reduction in the wage differential when controlling for firm fixed effects is largest for recent immigrants. Apparently, immigrants move into higher paying firms, and more similar to those of natives, as they spend time in the host country - an empirical pattern also uncovered in the recent studies of Aydemir and Skuterud (2008) and Pendakur and Woodcock (2010), both based on Canadian data. This conclusion is, however, premature, as any immigrant cohort heterogeneity is not accounted for in the table. In cross-sectional analyses, productivity differences across immigrant arrival cohorts and/or lasting effects of entry conditions will be reflected in the association between wages and YSM (Borjas, 1995; Åslund and Roth, 2007).

\subsection{Wage assimilation within and across establishments}

Figure 1 displays how the predicted wage, based on the coefficient estimates from the full synthetic panel model outlined in section 2 , evolves with years since entry (YSM) ${ }^{10}$ The upper panels show predicted log wages from the specification without firm fixed effects. The native profiles start at the median age of immigration, which is 25,26 , and 29 for the three education groups. The experience premium is relatively low for natives and amounts to about $0.2 \log$ point over the 25 year span, reflecting the compressed wage structure in Norway and its generally low returns to investments in human capital. Wages among immigrants grow with experience in Norway, but there is no convergence with native wages. Instead, the native-immigrant wage differential increases with additional years in the country. The widening gap arises from lower immigrant wage growth over the life cycle and this pattern is found for all education groups. The one exception is for highly educated immigrants, for whom wage growth beyond 15 years somewhat exceeds that of natives.

Worker sorting across firms matters. The middle panels display predicted log wages from the specification with firm fixed effects, drawn separately for a native and an immigrant employee in an establishment with a weighted average firm wage effect. For low and medium educated natives, wage growth with age is slightly lower in the "within-firm" panels than in the top panels, while the opposite is true for highly educated natives. Accounting for firm fixed effects reduces the native-immigrant wage differential for the relevant ranges of

\footnotetext{
${ }^{10}$ Estimates from the complete model are listed in the Appendix, Table A1.
} 
YSM and education: Comparing workers within the same establishment, immigrants and natives display relatively similar wage developments over time.

Figure 1. Predicted wages as function of years since migration (YSM).
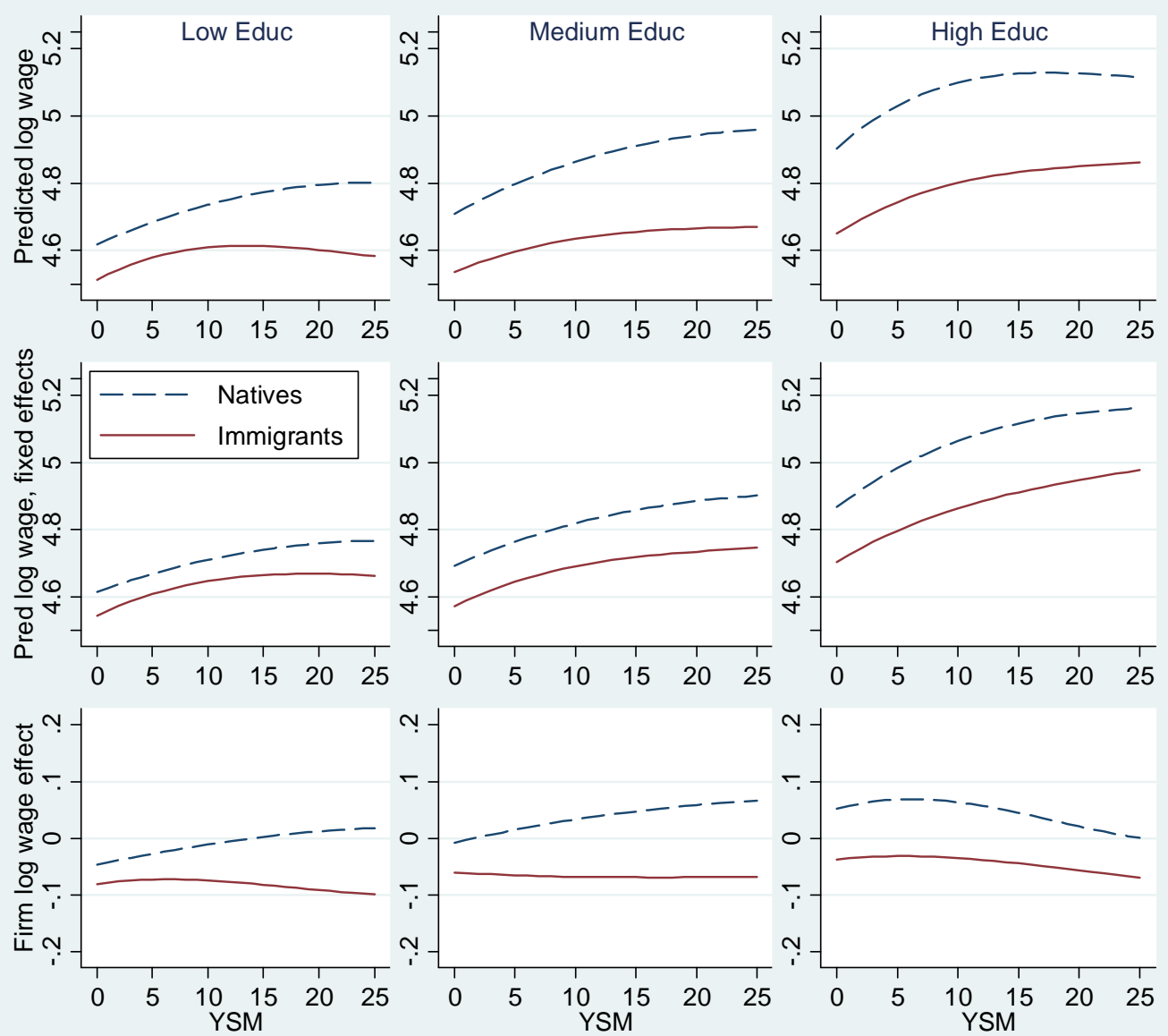

Note: For natives, predicted wages are drawn as a function of age, starting at the median age of arrival for immigrants in the respective education group $(25,26$, and 29). The upper panels are based on the standard model, while the middle panels are based on the firm fixed effects model. The lower panels stem from an auxiliary regression with the firm fixed effect expressed as a function of same explanatory variables as in the top panel and a linear time trend.

When we account for differences in the distribution of workers across firms, the native-immigrant wage differential is reduced for all relevant values of YSM. Immigrants tend to be stuck in firms that pay below average wages. The last point is illustrated in the bottom panels of Figure 1. These panels display the predicted firm-specific wage component against years since labor market entry for natives and immigrants, estimated from the 
auxiliary regression of the firm wage effect on the human capital variables included in the baseline specification and a time trend. Consider the middle panel, drawn for workers in the medium education bracket. The panel shows that the typical native worker in this education group starts out in a firm that pays an average wage, as the expected firm wage effect evaluated at $\mathrm{YSM}=0$ is about zero. Over time this worker is predicted to advance to higher paying firms, after 25 years ending up in a firm paying seven percent above the average firm. The figure shows clear signs of worker sorting in the sense that employees with low education also tend to work in low-paying firms. This holds for both immigrants and natives. With the exception of highly educated middle-aged workers, natives move to higher paying firms with age. ${ }^{11}$ For immigrants, the allocation across firms over the working career looks very different. For none of the three education groups is there any indication that immigrants move to better paying firms with time in Norway, as was suggested by the cross-sectional evidence described in Table 2. To reconcile the results of Table 2 and Figure 1, it is instructive to consider the estimated cohort effects from the wage equation, reported in appendix Table A1. These estimates reveal considerable permanent wage differences across entry cohorts, with higher wages for the cohorts that arrived during the 1960s and 1970s than those who arrived later. For example, immigrants who entered during the 1970s earn eight percent higher wages than the 1991-95 arrivals; see column 1. Columns 2 and 3 show that the source of this pay differential is that the early immigrants work in higher paying firms than the more recent arrivals, and that the favorable job affiliation is not the result of job mobility. What Figure 1 shows is that controlling for such differences across arrival cohorts effectively removes any trace of wage improvements from immigrant job mobility suggested by the unstandardized data.

Table 3 provides further details on the upper and middle panels of Figure 1, reporting the difference between the two wages profiles for selected values of YSM. To check for precision, the wage differentials are reported with standard errors. It is evident from the table that wages of immigrants are significantly below those of native workers with similar age and schooling. Based on the standard assimilation model without firm fixed effects (columns

\footnotetext{
${ }^{11}$ The decline in the firm fixed effect for highly educated native workers after 10 years in the labor market is perhaps best understood in light of the increasing within-firm wages over time for this group. The figure shows that highly educated, middle-aged, native workers on average move to lower paying firms over time, but also to a higher paying position in those firms, ensuring an overall positive wage growth as displayed in the upper panel. These wage patterns are, in our view, worthy of a separate study.
} 
1,3 , and 5), we find that wages of immigrants fall behind those of natives, and increasingly so for the low and medium educated, with time in the host country. After 20 years, the estimates for low and medium educated workers show that the native-immigrant wage differential has widened by about $0.10 \log$ point since one year after entry. When we control for firm fixed effects (columns 2 and 4), the widening of the wage gap over time is much smaller-about 0.02-0.03 log point. For highly educated workers, the wage differential is larger and close to one third of the gap can be attributed to differences in the distribution of workers across firms. For the highly educated, the native-immigrant wage differential remains relatively stable with age at about 20 percent when we account for firm fixed effects.

Table 3. Immigrant-native wage differential by years since migration.

\begin{tabular}{|c|c|c|c|c|c|c|}
\hline \multirow{3}{*}{$\begin{array}{l}\text { Years since } \\
\text { entry: }\end{array}$} & \multicolumn{2}{|c|}{ Low education } & \multicolumn{2}{|c|}{ Medium education } & \multicolumn{2}{|c|}{ High education } \\
\hline & \multirow[t]{2}{*}{ (1) } & \multirow[t]{2}{*}{ (2) } & \multirow[t]{2}{*}{$(3)$} & \multirow[t]{2}{*}{ (4) } & \multirow[t]{2}{*}{$(5)$} & \multirow[t]{2}{*}{ (6) } \\
\hline & & & & & & \\
\hline \multirow[t]{2}{*}{1} & -0.103 & -0.067 & -0.178 & -0.120 & -0.262 & -0.170 \\
\hline & $(0.007)$ & $(0.006)$ & $(0.007)$ & $(0.006)$ & $(0.010)$ & $(0.008)$ \\
\hline \multirow[t]{2}{*}{5} & -0.106 & -0.060 & -0.200 & -0.120 & -0.286 & -0.186 \\
\hline & $(0.003)$ & $(0.003)$ & $(0.004)$ & $(0.003)$ & $(0.005)$ & $(0.004)$ \\
\hline \multirow[t]{2}{*}{10} & -0.127 & -0.064 & -0.229 & -0.128 & -0.298 & -0.200 \\
\hline & $(0.003)$ & $(0.003)$ & $(0.003)$ & $(0.003)$ & $(0.005)$ & $(0.004)$ \\
\hline \multirow[t]{2}{*}{15} & -0.160 & -0.076 & -0.256 & -0.140 & -0.293 & -0.204 \\
\hline & $(0.004)$ & $(0.003)$ & $(0.004)$ & $(0.003)$ & $(0.005)$ & $(0.004)$ \\
\hline \multirow[t]{2}{*}{20} & -0.194 & -0.091 & -0.277 & -0.151 & -0.276 & -0.199 \\
\hline & $(0.006)$ & $(0.005)$ & $(0.006)$ & $(0.005)$ & $(0.007)$ & $(0.005)$ \\
\hline \multirow[t]{2}{*}{25} & -0.219 & -0.104 & -0.289 & -0.155 & -0.253 & -0.184 \\
\hline & $(0.008)$ & $(0.006)$ & $(0.008)$ & $(0.006)$ & $(0.009)$ & $(0.007)$ \\
\hline $\begin{array}{l}\text { Firm fixed } \\
\text { effects }\end{array}$ & No & Yes & No & Yes & No & Yes \\
\hline Controls & $\begin{array}{l}\text { Cubic poly1 } \\
\text { cohort fixe } \\
\text { immigrant) }\end{array}$ & $\begin{array}{l}\text { ls of age a } \\
\text { ts, log loc } \\
\text { calendar ye }\end{array}$ & $\begin{array}{l}\text { M, interac } \\
\text { mploymer } \\
\text { ed effects }\end{array}$ & $\begin{array}{l}\text { ith educat } \\
\text { (plus inte }\end{array}$ & $\begin{array}{l}\text { ittainment } \\
\text { is with att }\end{array}$ & $\begin{array}{l}\text { grant } \\
\text { nt and }\end{array}$ \\
\hline
\end{tabular}

As in Figure 1, the main finding in Table 3 contradicts the assimilation pattern of immigrant movement into high-wage firms over time suggested by the simpler crosssectional approach of Table 2. Several repeated cross sections enable us to control for immigrant arrival cohort heterogeneity, and the discrepancy between findings underscores the importance of accounting for cohort differences in outcomes. When we control for 
immigrant arrival cohort heterogeneity, we find no indication that immigrants on average move to higher paying firms with time in Norway.

\subsection{Years of work experience versus years since migration}

The lack of any wage convergence between immigrants and natives is puzzling as we expect foreign-borns to accumulate host-country specific human capital such as language skills over time. It is often argued that a substantial part of this learning process takes place at the workplace, adding to the overall human capital accumulation for both natives and immigrants through work. At the same time, prior evidence (e.g., Bratsberg et al., 2010) shows that immigrants are more frequently exposed to spells of unemployment and spend longer periods out of employment than natives. Table 4 displays the average number of years with employment by years since entry for immigrants and the corresponding age for natives. Employment is measured on the basis of annual earnings and a person is defined as employed if he earned positive labor earnings that year. According to the numbers in Table 4, immigrants do accumulate less experience through work but the difference is by no means dramatic. After 10 years, the average work experience differential between natives and immigrants is about 1.5 to 2 years across education groups.

Table 4. Actual work experience of immigrant and native workers by years since entry.

\begin{tabular}{lcccccc}
\hline & \multicolumn{2}{c}{ Low education } & \multicolumn{2}{c}{ Medium education } & \multicolumn{2}{c}{ High education } \\
Years since entry & Immigrants & Natives & Immigrants & Natives & Immigrants & Natives \\
\hline 1 & 0.65 & 0.80 & 0.68 & 0.78 & 0.70 & 0.77 \\
5 & 3.66 & 4.74 & 3.82 & 4.74 & 4.08 & 4.71 \\
10 & 7.69 & 9.67 & 7.90 & 9.68 & 8.20 & 9.63 \\
\hline
\end{tabular}

Note: For natives, "years since entry" is measured as years since age 26, 27, and 29 for the three education groups, respectively. These ages correspond to the median age at immigration for the three immigrant groups.

The weaker association between actual and potential work experience for immigrants, with the difference between YSM and actual work experience increasing in YSM, may explain why the wage profile with potential experience is less steep for immigrants than for natives. To check the implications for wage profiles we re-estimate the model including cumulative years out of employment as a control variable. Table 5, panel A, reports the marginal effect on wages of one year of absence from employment. With one exception (low education; no fixed effects), the evidence shows that a spell of non-employment has a more 
negative effect on the wages of immigrants than natives, consistent with the idea that accumulation of human capital through work is particularly important for immigrants. ${ }^{12}$

Table 5. Effects of one year out of employment and the immigrant-native wage differential by years since migration controlling for years of non-employment.

\begin{tabular}{|c|c|c|c|c|c|c|}
\hline & \multicolumn{2}{|c|}{ Low education } & \multicolumn{2}{|c|}{ Medium education } & \multicolumn{2}{|c|}{ High education } \\
\hline & (1) & (2) & (3) & (4) & (5) & (6) \\
\hline \multicolumn{7}{|c|}{$\begin{array}{l}\text { A. Marginal effect of one year out of } \\
\text { employment* }\end{array}$} \\
\hline Natives & $\begin{array}{l}-0.0055 \\
(0.0004)\end{array}$ & $\begin{array}{l}-0.0038 \\
(0.0003)\end{array}$ & $\begin{array}{l}0.0025 \\
(0.0005)\end{array}$ & $\begin{array}{l}-0.0018 \\
(0.0003)\end{array}$ & $\begin{array}{c}0.0005 \\
(0.0005)\end{array}$ & $\begin{array}{l}-0.0060 \\
(0.0004)\end{array}$ \\
\hline Immigrants & $\begin{array}{l}-0.0033 \\
(0.0012)\end{array}$ & $\begin{array}{l}-0.0051 \\
(0.0010)\end{array}$ & $\begin{array}{l}-0.0126 \\
(0.0016)\end{array}$ & $\begin{array}{l}-0.0092 \\
(0.0012)\end{array}$ & $\begin{array}{l}-0.0234 \\
(0.0021)\end{array}$ & $\begin{array}{l}-0.0169 \\
(0.0016)\end{array}$ \\
\hline \multicolumn{7}{|c|}{$\begin{array}{l}\text { B. Wage differential by } \\
\text { years since entry: }\end{array}$} \\
\hline 1 & $\begin{array}{l}-0.100 \\
(0.007)\end{array}$ & $\begin{array}{l}-0.065 \\
(0.006)\end{array}$ & $\begin{array}{l}-0.170 \\
(0.007)\end{array}$ & $\begin{array}{l}-0.116 \\
(0.006)\end{array}$ & $\begin{array}{l}-0.250 \\
(0.010)\end{array}$ & $\begin{array}{l}-0.164 \\
(0.008)\end{array}$ \\
\hline 5 & $\begin{array}{l}-0.103 \\
(0.004)\end{array}$ & $\begin{array}{l}-0.056 \\
(0.003)\end{array}$ & $\begin{array}{l}-0.184 \\
(0.004)\end{array}$ & $\begin{array}{l}-0.110 \\
(0.003)\end{array}$ & $\begin{array}{l}-0.261 \\
(0.006)\end{array}$ & $\begin{array}{l}-0.171 \\
(0.005)\end{array}$ \\
\hline 10 & $\begin{array}{l}-0.124 \\
(0.004)\end{array}$ & $\begin{array}{l}-0.059 \\
(0.003)\end{array}$ & $\begin{array}{l}-0.208 \\
(0.004)\end{array}$ & $\begin{array}{l}-0.115 \\
(0.003)\end{array}$ & $\begin{array}{l}-0.264 \\
(0.006)\end{array}$ & $\begin{array}{l}-0.179 \\
(0.005)\end{array}$ \\
\hline 15 & $\begin{array}{l}-0.155 \\
(0.005)\end{array}$ & $\begin{array}{l}-0.070 \\
(0.004)\end{array}$ & $\begin{array}{l}-0.234 \\
(0.005)\end{array}$ & $\begin{array}{l}-0.127 \\
(0.004)\end{array}$ & $\begin{array}{l}-0.258 \\
(0.006)\end{array}$ & $\begin{array}{l}-0.181 \\
(0.005)\end{array}$ \\
\hline 20 & $\begin{array}{l}-0.187 \\
(0.006)\end{array}$ & $\begin{array}{l}-0.085 \\
(0.005)\end{array}$ & $\begin{array}{l}-0.257 \\
(0.006)\end{array}$ & $\begin{array}{l}-0.139 \\
(0.005)\end{array}$ & $\begin{array}{c}-0.242 \\
(0.007)\end{array}$ & $\begin{array}{c}-0.177 \\
(0.006)\end{array}$ \\
\hline 25 & $\begin{array}{c}-0.212 \\
(0.008)\end{array}$ & $\begin{array}{c}-0.098 \\
(0.006) \\
\end{array}$ & $\begin{array}{l}-0.270 \\
(0.008)\end{array}$ & $\begin{array}{c}-0.144 \\
(0.006) \\
\end{array}$ & $\begin{array}{c}-0.220 \\
(0.010) \\
\end{array}$ & $\begin{array}{c}-0.162 \\
(0.008) \\
\end{array}$ \\
\hline $\begin{array}{l}\text { Firm fixed } \\
\text { effects }\end{array}$ & No & Yes & No & Yes & No & Yes \\
\hline Controls & $\begin{array}{l}\text { Cubic poly } \\
\text { educational } \\
\text { (plus intera }\end{array}$ & $\begin{array}{l}\text { ls of age } \\
\text { iment, in } \\
\text { with att }\end{array}$ & $\begin{array}{l}\mathrm{M} \text {, and yea } \\
\text { rant cohor } \\
\text { lent and im }\end{array}$ & $\begin{array}{l}\text { f non-emp } \\
\text { ed effects, } \\
\text { rant), and }\end{array}$ & $\begin{array}{l}\text { nent, all in } \\
\text { local unen } \\
\text { hdar year }\end{array}$ & $\begin{array}{l}\text { ted with } \\
\text { ment rate } \\
\text { effects }\end{array}$ \\
\hline
\end{tabular}

Differential accumulation of actual work experience accounts for some, but not very much of the immigrant-native wage differential (see Table 5, panel B). For example, comparing the predicted wage differentials 15 years after entry in Tables 4 and 5, we see that accounting for actual experience reduces the differential in the standard model from -0.160 to

\footnotetext{
${ }^{12}$ For native workers with medium and high education, estimates of the effect of one year of non-employment are (slightly) positive when the model does not account for firm wage effects. Since the estimates with firm fixed effects are negative, spells of non-employment may (in contrast to the results for immigrants) have a positive effect on establishment affiliation for natives with medium and high education. We do not have a good explanation for this result, but note that these groups are much less likely to have involuntary spells out of work than other workers, and we suspect that the positive returns may be due to education breaks, periods out of work in connection with geographic mobility, and the like.
} 
-0.155 for low education, from -0.256 to -0.235 for medium education, and, finally, from 0.293 to -0.258 for workers with high education. The impact of controlling for years out of employment is of similar magnitude for the estimated wage differentials based on the firm fixed effects model.

\subsection{Returns to seniority}

Even though wage profiles estimated with firm fixed effects are often labeled "within-firm" profiles, they do not distinguish between wage effects of firm-specific seniority and overall work experience. In a simple theoretical framework where workers accumulate both general and firm-specific human capital at the workplace we expect an extra compensation for workers who keep extended company with the same employer. Other theories emphasize incentives, insurance, and sorting as mechanisms behind wage policies with deferred compensation. From our wage differential perspective, immigrants are penalized if they have less seniority (e.g., due to shorter contracts and more frequent layoffs) or if their returns to firm-specific experience are lower than those of native workers.

To investigate seniority effects on wages, we merge into the wage data information about the job spell taken from payroll records in the employee register. ${ }^{13}$ The payroll records include information on the contract starting date that enables us to construct an individual seniority variable. In this section we present results from similar models as above, but augmented with a seniority term (cubic polynomial). Figure 2 displays the predicted seniority premiums for immigrants and natives by education and estimation method. According to the plots in the top panels (which do not account for firm wage effects), immigrants who stay in the same firm for ten years receive a wage premium of close to 9 percent. This premium partly reflects the fact that immigrant employees with high seniority work in firms that pay more, and the firm fixed effects estimates displayed in the lower panels indicate a ten-year seniority premium of about 5-6 percent for low and medium education workers and 3 percent for highly educated immigrants. When estimates of seniority returns fall as we include firm fixed effects in the empirical model, the indication is that the first set of estimates are upwardly biased from a positive correlation between seniority and the firm wage component.

\footnotetext{
${ }^{13}$ The merge procedure led to a slight reduction in sample size-from 4,918,260 to 4,745,275 observationscaused by some occurrences of non-matching employer identifiers in the two data sources.
} 
As Figure 2 shows, accounting for this correlation is important when estimating seniority returns for immigrants in general as well as for highly educated native workers. Our preferred estimates for natives, based on the firm fixed effects model, reveal a premium close to 8 percent after 10 years, remarkably similar across education groups. For the highly educated group, immigrants earn significantly lower seniority returns than natives. But for workers with low and medium education, seniority profiles are similar for immigrants and natives. $^{14}$

Figure 2. Estimated seniority premiums.

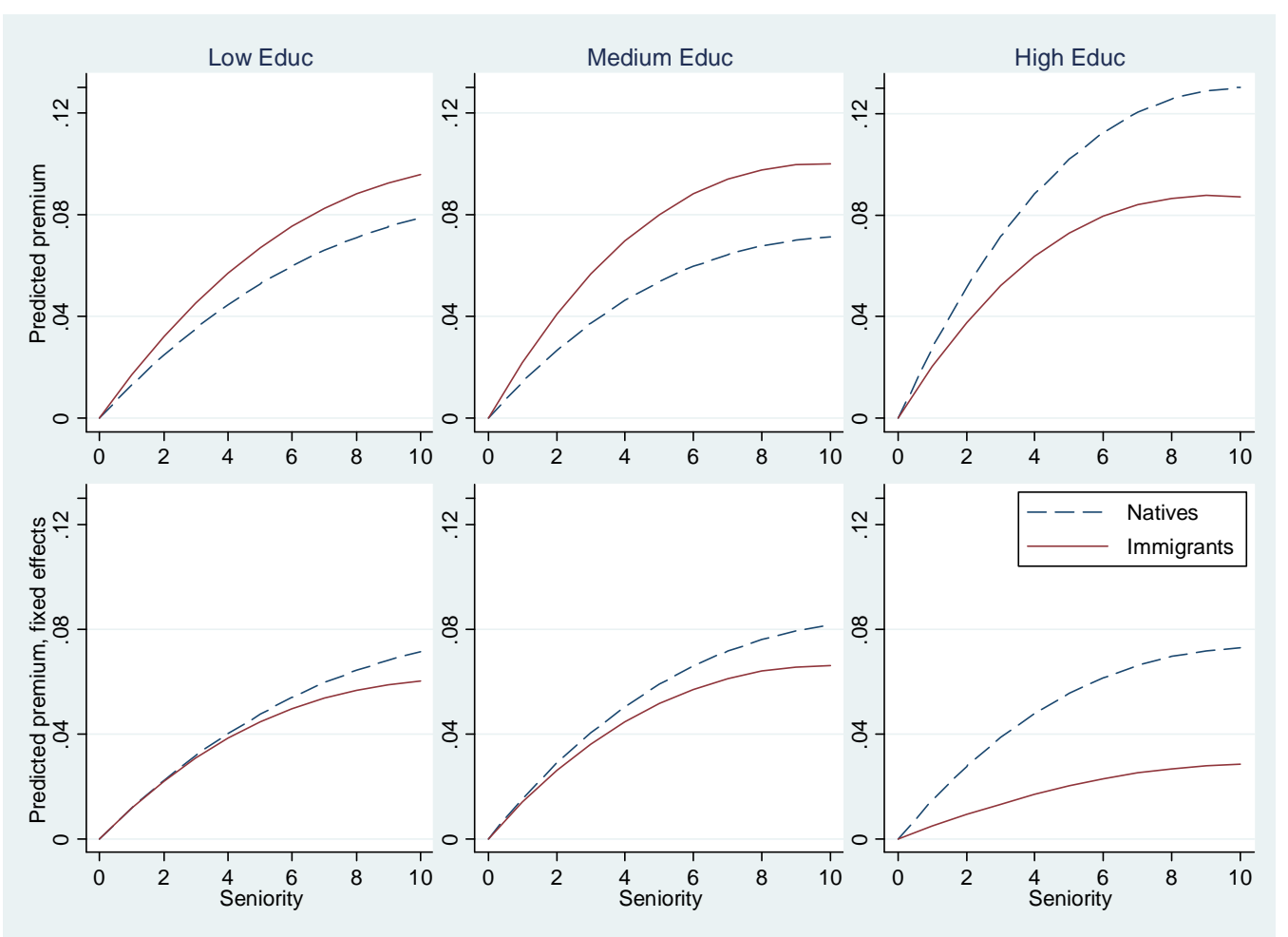

Our estimated seniority returns are in line with previous Norwegian studies like Barth (1997), but lower than estimates from U.S. studies, where, for example, the 11 percent premium after ten years reported by Altonji and Williams (2005) is in the lower range of a highly divergent literature. The comparison may however be as expected, in light of the less individualized wage setting in Norway than in the United States.

\footnotetext{
${ }^{14}$ Evaluated at the mean level of seniority for immigrants (4 years), the null hypothesis of equal seniority premiums for immigrants and natives is rejected only for workers with high education.
} 
Even in cases where wage returns to seniority are similar for immigrants and natives, differences in layoffs and quits may generate differential seniority patterns by immigrant status. Since immigrants in our sample arrived as adults, they have on average had less time to accumulate seniority than natives. Table 6 reports average seniority by immigrant status and educational attainment. For all educational groups, immigrants have substantially less seniority than natives. Seniority is decreasing in education for natives, reflecting differences in mobility rates and post-schooling years in the labor market. Table 6 also indicates that job change is more common among immigrants than natives. A striking pattern is that a much larger fraction of immigrant job change is involuntary as it is more likely for immigrants to experience an intermittent spell of unemployment between jobs.

Table 6. Workplace seniority and involuntary job change of immigrants and natives.

\begin{tabular}{|c|c|c|c|c|c|c|}
\hline & \multicolumn{2}{|c|}{ Low education } & \multicolumn{2}{|c|}{ Medium education } & \multicolumn{2}{|c|}{ High education } \\
\hline & Immigrants & Natives & Immigrants & Natives & Immigrants & Natives \\
\hline Seniority (years) & 3.75 & 8.52 & 4.07 & 6.88 & 3.58 & 5.55 \\
\hline Share new job & .175 & .075 & .153 & .088 & .177 & .126 \\
\hline Share involuntary & & & & & & \\
\hline job change & .554 & .341 & .438 & .220 & .293 & .096 \\
\hline
\end{tabular}

In Figure 3 we display the predicted wage profiles based on a regression model where we also we control for seniority with the same employer. ${ }^{15}$ Compared to Figure 1 , the wageexperience profiles plotted in Figure 3 do not change fundamentally. The native-immigrant wage differential is however lower when seniority controls are included (in addition to years of non-employment controls). Particularly for the low and medium education groups, the general pattern of divergence remains and is largely explained by the lack of immigrant mobility into better paying firms. Details on the immigrant-native wage differential are provided in Table 7, and the impact of seniority controls follows from a comparison with differentials listed in Table 5. Evaluated at 10 years of residence and based on the firm-fixed effects estimates, the differential drops (in absolute value) from -0.059 to -0.046 for the low education group. While the medium education differential changes from -0.115 to -0.099 , the

\footnotetext{
${ }^{15}$ The profiles are evaluated at a seniority level of zero; that is, they isolate cumulative market returns to experience.
} 
largest impact is found for the highly educated, from -0.179 to -0.145 , the group for whom immigrant returns to seniority fall significantly below those of native workers.

Figure 3. Wage profiles estimated with controls for seniority and years of non-employment.
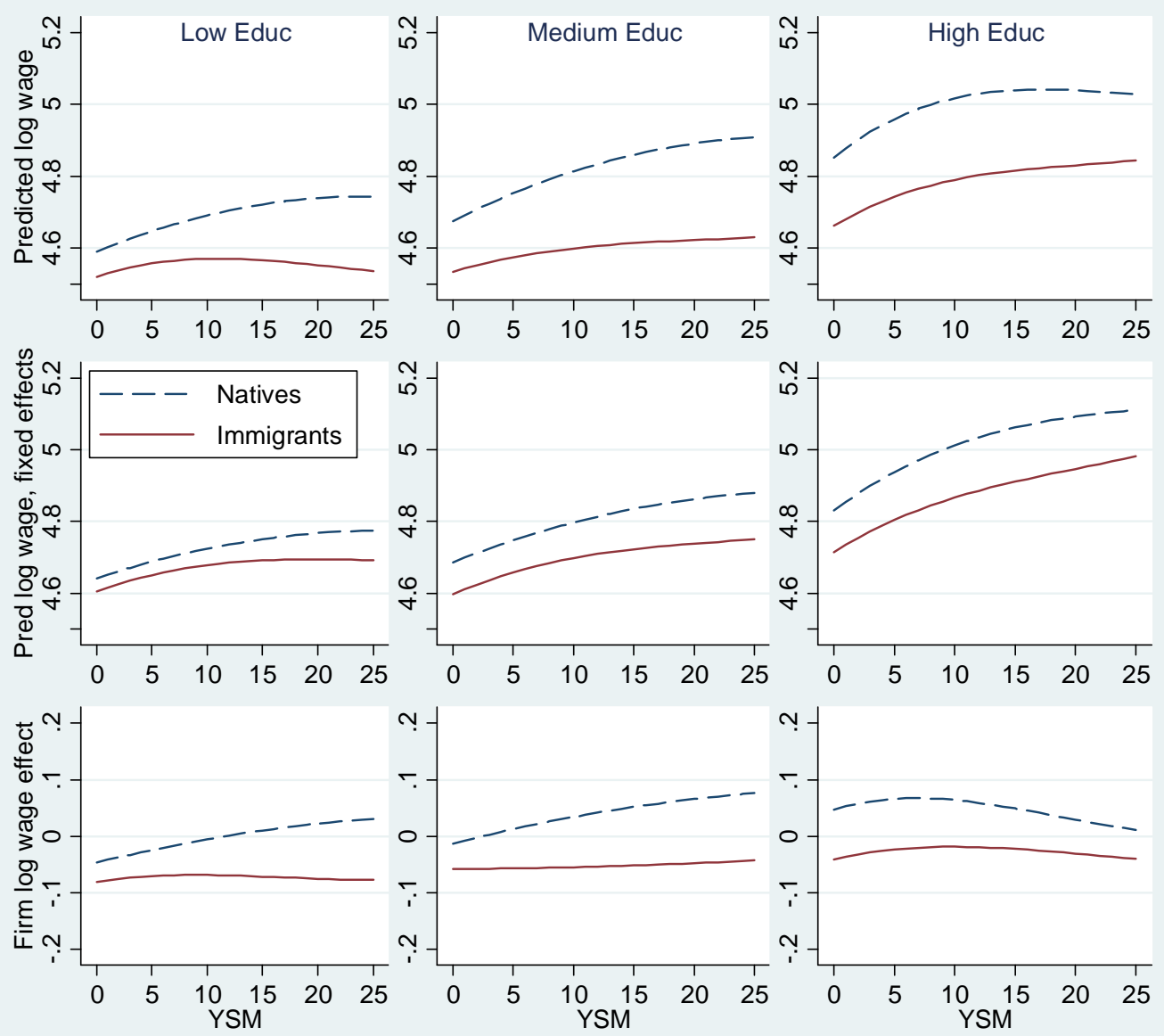

In sum, differences in actual work experience and seniority explain a non-trivial part of the immigrant-native wage differential. Evaluated at 10 years since migration, the estimated within-firm differential for low educated workers is reduced from -0.064 (Table 3) to -0.046 (Table 7). For medium education, the differential goes from -0.128 to -0.099 and from -0.200 to -0.145 for the highly educated. All in all, about one quarter of the estimated immigrant-native wage differential that accounts for firm fixed effects (listed in Table 2) can be attributed to differences in actual work experience and seniority. 
Table 7. Immigrant-native wage differential by years since migration, with controls for years of non-employment and seniority.

\begin{tabular}{|c|c|c|c|c|c|c|}
\hline & \multicolumn{2}{|c|}{ Low education } & \multicolumn{2}{|c|}{ Medium education } & \multicolumn{2}{|c|}{ High education } \\
\hline & $(1)$ & $(2)$ & (3) & (4) & (5) & $(6)$ \\
\hline \multicolumn{7}{|l|}{$\begin{array}{l}\text { Years since } \\
\text { entry: }\end{array}$} \\
\hline 1 & $\begin{array}{l}-0.073 \\
(0.007)\end{array}$ & $\begin{array}{l}-0.036 \\
(0.006)\end{array}$ & $\begin{array}{l}-0.148 \\
(0.008)\end{array}$ & $\begin{array}{l}-0.089 \\
(0.006)\end{array}$ & $\begin{array}{l}-0.197 \\
(0.010)\end{array}$ & $\begin{array}{l}-0.120 \\
(0.009)\end{array}$ \\
\hline 5 & $\begin{array}{l}-0.090 \\
(0.005)\end{array}$ & $\begin{array}{l}-0.038 \\
(0.004)\end{array}$ & $\begin{array}{l}-0.178 \\
(0.005)\end{array}$ & $\begin{array}{l}-0.090 \\
(0.004)\end{array}$ & $\begin{array}{l}-0.217 \\
(0.007)\end{array}$ & $\begin{array}{l}-0.133 \\
(0.005)\end{array}$ \\
\hline 10 & $\begin{array}{l}-0.120 \\
(0.005)\end{array}$ & $\begin{array}{l}-0.046 \\
(0.004)\end{array}$ & $\begin{array}{l}-0.215 \\
(0.005)\end{array}$ & $\begin{array}{l}-0.099 \\
(0.004)\end{array}$ & $\begin{array}{l}-0.227 \\
(0.007)\end{array}$ & $\begin{array}{l}-0.145 \\
(0.005)\end{array}$ \\
\hline 15 & $\begin{array}{l}-0.155 \\
(0.006)\end{array}$ & $\begin{array}{l}-0.059 \\
(0.005)\end{array}$ & $\begin{array}{l}-0.246 \\
(0.006)\end{array}$ & $\begin{array}{l}-0.112 \\
(0.004)\end{array}$ & $\begin{array}{l}-0.224 \\
(0.007)\end{array}$ & $\begin{array}{l}-0.151 \\
(0.006)\end{array}$ \\
\hline 20 & $\begin{array}{l}-0.187 \\
(0.007)\end{array}$ & $\begin{array}{l}-0.073 \\
(0.006)\end{array}$ & $\begin{array}{l}-0.269 \\
(0.007)\end{array}$ & $\begin{array}{l}-0.124 \\
(0.006)\end{array}$ & $\begin{array}{l}-0.209 \\
(0.009)\end{array}$ & $\begin{array}{l}-0.146 \\
(0.007)\end{array}$ \\
\hline 25 & $\begin{array}{l}-0.208 \\
(0.009)\end{array}$ & $\begin{array}{l}-0.084 \\
(0.007)\end{array}$ & $\begin{array}{l}-0.279 \\
(0.009)\end{array}$ & $\begin{array}{l}-0.128 \\
(0.007)\end{array}$ & $\begin{array}{l}-0.185 \\
(0.011)\end{array}$ & $\begin{array}{l}-0.128 \\
(0.008)\end{array}$ \\
\hline $\begin{array}{l}\text { Firm fixed } \\
\text { effects }\end{array}$ & No & Yes & No & Yes & No & Yes \\
\hline Controls & $\begin{array}{l}\text { Cubic poly } \\
\text { interacted } \\
\text { unemploy! } \\
\text { year fixed }\end{array}$ & $\begin{array}{l}\text { als of ag } \\
\text { education } \\
\text { rate (plus } \\
\text { ts }\end{array}$ & $\begin{array}{l}\text { 4, years } \\
\text { inment, } \\
\text { ctions w }\end{array}$ & $\begin{array}{l}\text {-emplo } \\
\text { rant co } \\
\text { ainmen }\end{array}$ & $\begin{array}{l}\text { and seni } \\
\text { ked effect } \\
\text { nmigrant }\end{array}$ & $\begin{array}{l}\text { all } \\
\text { local } \\
\text { calendar }\end{array}$ \\
\hline
\end{tabular}

Note: See note to Table 3.

\subsection{Firm wage effects and the distribution of immigrants across establishments}

Immigrant workers are not only underrepresented in high-paying firms, but as in a recent study from Sweden (Åslund and Nordström Skans, 2010), they are overexposed to coworkers of their own origin. On average, immigrants work in establishments where one quarter to one third of the workforce also are immigrants from low-income source countries, with the higher fraction for those with low education (see Table 1). Segregation of immigrants and natives across firms raises questions about the interpretation of the estimated firm wage effects. One concern is that any relation between the workplace immigrant share and the firm wage effect might differ for native and immigrant workers, with immigrants more penalized than natives from working in immigrant-intensive firms. Further, sorting of workers in terms of unobservable individual wage determinants will influence estimates of the firm wage effect, and such sorting may differ for natives and immigrants, e.g., when lowability immigrants are more likely than low-ability natives to work in firms with a high 
immigrant share. In both cases, segregation of immigrants and natives across firms might lead us to overstate any negative wage effect of firms with many immigrant employees.

To check whether our results are sensitive to such concerns, we re-estimate the model basing estimates of firm wage effects on native employees only. The top row of Figure 4 displays the resulting wage profiles, after adjusting immigrant wages for native fixed firm effects. Apart from differences in intercepts, the YSM/experience profiles are remarkably similar for natives and immigrants with a steeper wage profile for more educated workers. The immigrant-native wage gap remains almost constant over time for all three education groups. When we adjust for the native fixed firm effect, the differential is about 9 percent for workers with low education, 11 percent for medium, and 14 percent for highly educated workers (see Table A2 for details).

Figure 4. Predicted log wage and seniority profiles estimated with native fixed firm effects.
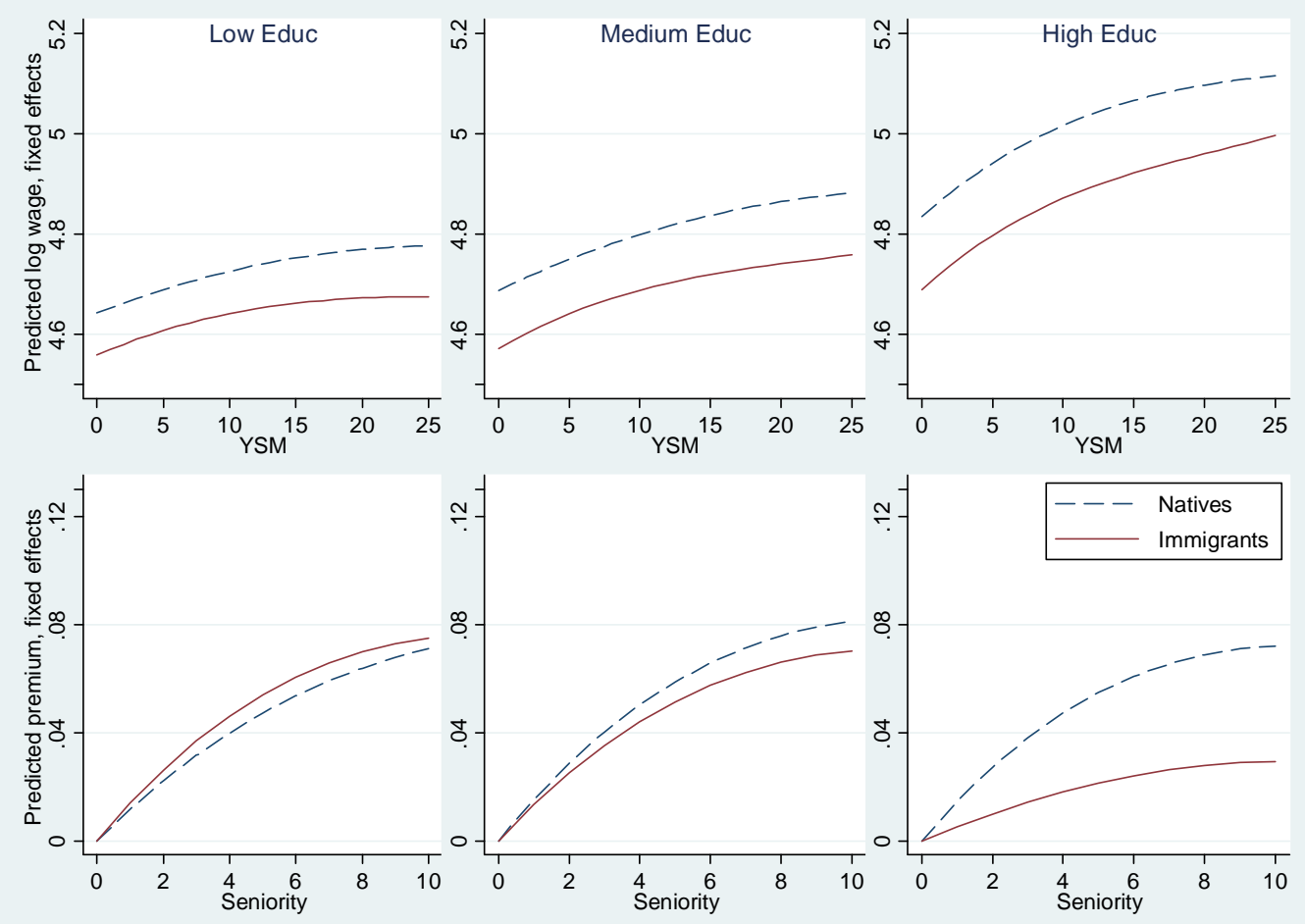

The seniority profiles displayed in the bottom row of Figure 4 are very similar to those presented above and based on jointly estimated firm wage effects for natives and immigrants. Overall, our main findings are not sensitive to whether the fixed firm effects are 
based on the sample of natives or on all workers. ${ }^{16}$ Neither measure of the firm wage effect gives any indication that immigrant workers from developing countries over their career gradually enter firms where native workers enjoy high wages.

\section{Discussion}

Our analyses show that wages of immigrants from developing countries over time do not converge to those of natives with similar educational attainment, but rather that nativeimmigrant wage differentials increase with years in Norway. The divergence arises from lower, albeit positive, immigrant wage growth over the life cycle. ${ }^{17}$ Our focus is whether the expanding native-immigrant wage gap is driven by differential wage growth within firms or by differences in wage gains from job mobility over the career.

The evidence points to differences in the distribution of workers across firms as the key source of the widening wage gap. While native employees typically move to higher paying firms as they gain labor market experience, we fail to uncover evidence of such favorable job mobility for immigrants. In fact, for immigrants from developing countries the firm wage effect remains constant over the career. Even if our study is unable to pinpoint the exact mechanisms, the empirical evidence gives indications of the major causes of the observed differences in the role of job mobility.

Variation in involuntary job separations and disproportional exposure to unemployment are potential explanations, as the nature of job mobility is important for the associated wage change. While many displaced workers must accept a wage cut in order to obtain a new job, see Gibbons and Katz (1991) and Ruhm (1991) as well as Huttunen et al. (2011) for a Norwegian study of income loss following displacement, direct job-to-job movements are more likely to involve a wage gain. Referring back to Table 6 , we find that fully 17.5 percent of low-educated immigrant workers in the wage sample held a new job (i.e., had less than six months of seniority) and that more than half of these new job spells involved an intermittent period of registered unemployment. Indeed, the prevalence of

\footnotetext{
${ }^{16}$ The correlation between the firm fixed effects estimated with and without immigrants included is above 0.99 in the native sample and 0.87 in the immigrant sample.

${ }^{17}$ Barth et al (2004) show that the earnings gap between immigrants and natives in Norway, measured in terms of annual earnings, shrinks during the first ten years in the country. The fact that we do not find wage assimilation in terms of hourly wage in the present paper suggests that the annual earnings assimilation of immigrants observed in the prior study primarily is driven by rising relative employment and/or hours worked.
} 
movements in and out of jobs in combination with periods of unemployment is three to four times higher among immigrant than native workers. Hiring and firing policy based on "last in, first out" (LIFO) rules may explain why immigrants in general are more exposed to involuntary job separations. But as immigrants acquire work experience in Norway, we would expect them to take advantage of LIFO conventions and achieve protection from job loss similar to that of natives. The finding that wage gains from job mobility remain nonexistent even after 10 to 15 years in the host country cannot be explained by neutral LIFO rules.

The lack of immigrant wage growth from job mobility is consistent with discrimination in hiring. When job offer arrival rates are lower for immigrants, whether due to taste-based or statistical discrimination by employers who are less precisely informed about the productivity of immigrant applicants, ${ }^{18}$ wage gains from job mobility will be less frequent for immigrants than for native workers. The impact of less favorable outside opportunities caused by discrimination is likely to be reinforced by involuntary job separations and thereby create a regime where immigrants are trapped in low-paying jobs.

Our results do not, on the other hand, indicate that limited information about job opportunities is a major reason for why immigrants are paid less than natives. Information disadvantages would be expected to fade and access to high-wage firms improve over time, which is contrary to what we find.

Another key result is that, once we account for fixed firm effects, estimates of returns to seniority do not vary much between natives and immigrants, at least for workers with low and medium levels of educational attainment. This finding echoes results from the U.S. literature studying seniority returns by race (e.g., Bratsberg and Terrell, 1998). The empirical pattern debunks the explanation that differential accumulation of firm-specific human capital and differences in within-firm career opportunities are the sources of the widening wage gap. In a statistical discrimination framework, one could interpret differences in returns to seniority as indication of information asymmetries where employers update their information

\footnotetext{
${ }^{18}$ In a recent study from Sweden, Carlsson and Rooth (2007) draw on fictitious job applications and show that ethnic minority applicants are less likely to receive callbacks from employers than applicants with equal qualifications and a Swedish-sounding name. Holden and Rosén (2009) show that, in a search framework with employment protection, the presence of some discriminating employers will sustain a labor market equilibrium where discriminated workers are subject to stricter hiring standards.
} 
about true worker productivity. Even if such mechanisms imply higher seniority returns for immigrants, the relatively unfavorable evolvement of their outside option can be expected to weaken their bargaining position and counteract any additional wage growth from information updating.

An implication of statistical discrimination in hiring is that immigrants will invest less time in on-the-job search and be less likely than their native co-workers to quit a job in a high-pay firm. This mechanism will generate a stronger correlation between the firm wage effect and on-the-job seniority among immigrant workers than natives. Our finding that accounting for firm fixed effects in the wage equation affects estimated seniority returns more for immigrants than for natives shows that seniority indeed relates more strongly to firm pay for immigrant workers, and lends further credence to the interpretation that immigrant job mobility is hampered by statistical discrimination.

For highly educated workers, the seniority profile is less steep for immigrants than for natives. Highly educated immigrants are better paid and earn higher returns to general experience than immigrants with less schooling, but their returns to firm-specific experience are lower than for other immigrant groups as well as for natives. Limited transferability and lower quality of foreign education are two plausible explanations.

Workplace segregation by ethnicity may explain why immigrants from developing countries do not move to higher paying firms over time. Our data show that immigrants tend to work in establishments with high immigrant employment shares, which is in line with recent evidence from Sweden presented by Åslund and Nordström Skans (2010) who further find that immigrant wages are lower for workers with a high number of immigrant colleagues. While workplace segregation in the Swedish study is "a phenomenon that diminishes but does not disappear with time in the host country" (p. 482), we find that the share of immigrant workers at the establishment is unrelated to years in Norway. ${ }^{19}$ Even if neither study is designed to give the association between workplace immigrant shares and wages a causal interpretation, the absence of wage gains from job mobility uncovered in the present study fits well with the finding that the share of immigrant co-workers stays constant over time.

\footnotetext{
${ }^{19}$ When we estimate a model with the immigrant workplace share as a function of all observed characteristics of the wage equation, we find no systematic association between the immigrant share and years since entry.
} 
Recent studies of immigrant wages based on Canadian employer-employee data suggest that immigrants move into higher paying firms with time in the host country (Aydemir and Skuterud, 2008; Pendakur and Woodcock, 2010). At first glance, we too find evidence that this mechanism plays a role in the economic assimilation process of immigrants in Norway. But when we estimate wage profiles controlling for immigrant cohort differences, the finding of favorable immigrant job mobility disappears. Our results show that the early entry cohorts tend to work in better paying firms and that this advantage appears to be an attribute of the early arrival cohorts rather than a result of wage progress from job shopping.

We present no direct evidence on why the early immigrant entry cohorts tend to work in better paying firms throughout their career. Their favorable job affiliations may be related to conditions in the labor market at the time of entry, for instance created by the high demand for manufacturing workers during the 1970 s, or to the fact that there were very few immigrants from developing countries present in Norway at the time and therefore little segregation in the labor market. Alternatively, the pattern may reflect selection of firms and long-term survival of productive jobs along the lines of Jovanovic (1982), paired with higher rates of labor market withdrawal, or even return migration, among the early migrants who experienced job destruction (Bratsberg et al, 2010). Obviously, we cannot show that similar immigrant arrival cohort heterogeneity also drives the results in the Canadian studies, but the substantial differences in entry earnings among immigrants to Canada cited by Aydemir and Skuterud (2005) hint that this might be an issue.

\section{Conclusions}

We present evidence on the immigrant-native hourly wage differential in Norway by means of an extended assimilation regression framework in which wages are functions of experience, or years since migration for immigrants, accounting for firm fixed effects and arrival cohort heterogeneity. While economic assimilation studies typically find that earnings of immigrants initially grow faster than those of natives, we find that hourly wages of immigrants from developing countries grow over time, but fail to match the growth of native wages over the life cycle. An initial wage gap at entry expands with years in the host country. 
When we account for differences in returns to and patterns of job mobility with firm fixed effects, we find that about 40 percent of the native-immigrant wage gap is due to the fact that immigrants work and stay in low-paying firms. Immigrants appear to be stuck in firms that pay below average wages. Natives, in particular those with low and medium levels of educational attainment, typically work in establishments with pay below the firm average during early stages of their career and then proceed to improve their relative position in the hierarchy of establishments. Immigrants too tend to start their host-country career in lowpaying establishments, but fail to advance to higher paying firms over time.

Controlling for heterogeneity in firm pay, our results show that immigrant and native workers earn similar cumulative returns to host-country labor market experience. Further, at least for low and medium education workers, we find no evidence of differences in immigrant and native returns to firm seniority. These empirical patterns discredit such explanations as lack of information about the host-country labor market and its job opportunities, language barriers, limited access to native networks, and inferior promotions as major sources of differences in life cycle wage growth of immigrants and natives. Instead, our empirical evidence is consistent with persistent statistical discrimination in hiring as an important driver of the widening native-immigrant wage gap. Immigrants face less favorable options outside their own workplace and the negative impacts on wage gains from job mobility are reinforced by their higher rate of involuntary job separations. 


\section{References}

Åslund, Olof, and Oskar Nordström Skans (2010), "Will I See You at Work? Ethnic Workplace Segregation in Sweden, 1985-2002," Industrial \& Labor Relations Review, Vol. 63, No. 3, 471-493.

Åslund, Olof, and Dan-Olof Rooth (2007), "Do When and Where Matter? Initial Labor Market Conditions and Immigrant Earnings," The Economic Journal, Vol. 117, Issue $518,422-448$.

Abowd, John M., Francis Kramarz, and David N. Margolis (1999), "High Wage Workers and High Wage Firms," Econometrica, Vol. 67, No. 2, 251-333.

Abowd, John M, Francis Kramarz, Sebastien Perez-Duarte, and Ian M. Schmutte (2009), “A Formal Test of Assortative Matching in the Labor Market," NBER Working Paper No. 15546.

Abowd, John M., Paul Lengermann, and Kevin L. McKinney (2003), "The Measurement of Human Capital in the US Economy," Technical Report TP-2002-09 LEHD, U.S. Census Bureau.

Altonji, Joseph G., and Nicolas Williams (2005), "Do Wages Rise with Job Seniority? A Reassessment," Industrial \& Labor Relations Review, Vol. 58, No. 3, 370-397.

Aydemir, Abdurrahman, and Mikal Skuterud (2005), "Explaining the Deteriorating Entry Earnings of Canada's Immigrant Cohorts, 1966-2000," Canadian Journal of Economics, Vol. 38, No. 2, 641-672.

Aydemir, Abdurrahman, and Mikal Skuterud (2008), "The Immigrant Wage Differential Within and Across Establishments," Industrial \& Labor Relations Review, Vol. 61, No. 3, 334-352.

Barth, Erling (1997), "Firm-Specific Seniority and Wages," Journal of Labor Economics, Vol. 15, No. 3, 495-506.

Barth, Erling, Bernt Bratsberg, and Oddbjørn Raaum (2004), "Identifying Earnings Assimilation of Immigrants under Changing Macroeconomic Conditions," Scandinavian Journal of Economics, Vol. 106, No. 1, 1-22.

Barth, Erling, and Harald Dale-Olsen (2009), "Monopsonistic discrimination, worker turnover, and the gender wage gap," Labour Economics, Vol. 16, No. 5, 589-597.

Becker, Gary S. (1975), Human Capital. Chicago: University of Chicago Press.

Borjas, George J. (1995), “Assimilation and changes in cohort quality revisited: what happened to immigrant earnings in the 1980s?" Journal of Labor Economics, Vol. 13, No. 2, 201-245. 
Borjas, George J. (1999), "The Economic Analysis of Immigration.” In Handbook of Labour Economics, Vol. 3, edited by Orley C. Ashenfelter and David Card, pp. 1697-1760. Amsterdam: Elsevier.

Bowlus, Audra J., and Zvi Eckstein (2002), "Discrimination and Skill Differences in an Equilibrium Search Model," International Economic Review, Vol. 43, No. 4, 13091345.

Bratsberg, Bernt, Erling Barth, and Oddbjørn Raaum (2006), "Local Unemployment and the Relative Wages of Immigrants: Evidence from the Current Population Surveys," Review of Economics and Statistics, Vol. 88, No. 2, 243-263.

Bratsberg, Bernt, Oddbjørn Raaum, and Knut Røed (2010), "When Minority Labor Migrants meet the Welfare State," Journal of Labor Economics, Vol. 28, No. 3, 633-676.

Bratsberg, Bernt, Oddbjørn Raaum, and Kjetil Sørlie (2007), "Foreign-born Migration to and from Norway," in Caglar Ozden and Maurice Schiff (eds.), International Migration, Economic Development, \& Policy, New York: World Bank and Palgrave Macmillan.

Bratsberg, Bernt, and Dek Terrell (1998), "Experience, Tenure, and Wage Growth of Young Black and White Men," Journal of Human Resources, Vol. 33, No. 3, 658-682.

Card, David, Fransisco Devicienti, and Agata Maida (2010), "Rent-Sharing, Holdup, and Wages: Evidence from Matched Panel Data,” NBER Working Paper No. 16192.

Carlsson, Magnus, and Dan-Olof Rooth (2007), "Evidence of Ethnic Discrimination in the Swedish Labor Market using Experimental Data," Labour Economics Vol. 14, No. 4, 716-729.

Eckstein, Zvi, and Yoram Weiss (2004), "On the Wage Growth of Immigrants: Israel, 19902000," Journal of the European Economic Association, Vol. 2, No. 4, 665-695.

Farmer, Amy, and Dek Terrell (1996), "Discrimination, Bayesian Updating of Employer Beliefs, and Human Capital Accumulation," Economic Inquiry, Vol. 34, No. 2, 204219.

Fernandez, Roberto M., and Isabel Fernandez-Mateo (2006), "Networks, Race, and Hiring," American Sociological Review, Vol. 71, No. 1, 42-71.

Friedberg, Rachel M. (2000), "You Can't Take It With You? Immigrant Assimilation and the Portability of Human Capital," Journal of Labor Economics, Vol. 18, No. 2, 221-251.

Gibbons, Robert, and Lawrence F. Katz (1991), "Layoffs and Lemons," Journal of Labor Economics, Vol. 9, No. 4, 351-380. 
Groshen, Erica L. (1991), "Sources of Intra-Industry Wage Dispersion: How Much Do Employers Matter?” Quarterly Journal of Economics, Vol. 106, No. 3, 869-884.

Holden, Steinar, and Åsa Rosén (2009), "Discrimination and Employment Protection," CESifo Working Paper No. 2822.

Huttunen, Kristiina, Jarle Møen, and Kjell G. Salvanes (2011), "How Destructive is Creative Destruction? Effects of Displacement on Labor Force Withdrawal, Within-Firm Labor Mobility, and Earnings," Journal of the European Economic Association, forthcoming.

Jovanovic, Boyan (1982), "Selection and the Evolution of Industry," Econometrica, Vol. 50, No. 3, 649-670.

Lazear, Edward P. (1981), “Agency, Earnings Profiles, Productivity, and Hours Restrictions," American Economic Review, Vol. 71, No. 4, 606- 620.

Manning, Alan, and Joanna Swaffield (2008), "The Gender Gap in Early Career Wage Growth," The Economic Journal, Vol. 118, Issue 530, 983-1024.

McDonald, James T., and Christopher Worswick (1998), "The Earnings of Immigrant Men In Canada: Job Tenure, Cohort, and Macroeconomic Conditions," Industrial \& Labor Relations Review, Vol. 51, No. 3, 465-482.

Oettinger, Gerald S. (1996) "Statistical Discrimination and the Early Career Evolution of the Black-White Wage Gap,” Journal of Labor Economics, Vol. 14, No. 1, 52-78.

Patacchini, Eleonora, and Yves Zenou (2008), "Ethnic Networks and Employment Outcomes," IZA Discussion Paper No. 3331.

Pendakur, Krishna, and Simon Woodcock (2010), "Glass Ceilings or Glass Doors? Wage Disparity Within and Between Firms," Journal of Business and Economic Statistics, Vol. 28, No. 1, 181-189.

Raaum, Oddbjørn, and Knut Røed (2006), "Do Business Cycle Conditions at the Time of Labor Market Entry Affect Future Employment Prospects?" The Review of Economics and Statistics, Vol. 88, No. 2, 193-210.

Reingold, David A. (1999), "Social Networks and the Employment Problem of the Urban Poor," Urban Studies, Vol. 36, No. 11, 1907-1932.

Ruhm, Christopher J., (1991), “Are Workers Permanently Scarred by Job Displacements?” American Economic Review, Vol. 81, No. 1, 319-324.

Shimer, Robert (2005), "The Assignment of Workers to Jobs in an Economy with Coordination Frictions,” Journal of Political Economy, Vol. 113, No. 5, 996-1025. 
Statistics Norway (2005), Lønnsstatistikk (Wage Statistics) 2005, D 362 Norges offisielle statistikk (Official Statistics of Norway).

Topel, Robert H., (1991), "Specific Capital, Mobility and Wages: Wages Rise with Job Seniority," Journal of Political Economy, Vol. 99, No. 1, 145-176.

Topel, Robet H., and Michael P. Ward (1992), "Job Mobility and the Careers of Young Men," Quarterly Journal of Economics, Vol. 107, No. 2, 439-479.

Weiss, Yoram, Robert M. Sauer, and Menachem Gotlibovski (2003), "Immigration, Search, and Loss of Skill," Journal of Labor Economics, Vol. 2, No. 3, 557-591.

Welch, Finis (1979), "Effects of Cohort Size on Earnings: The Baby Boom Babies' Financial Bust," Journal of Political Economy, Vol. 87, No. 5, S65-S97. 


\section{Appendix}

Table A1: Detailed regression results.

\begin{tabular}{|c|c|c|c|c|c|c|}
\hline \multirow{3}{*}{$\begin{array}{l}\text { Dependent variable: } \\
\text { Model: }\end{array}$} & \multicolumn{3}{|c|}{ Baseline Specification (Fig. 1) } & \multicolumn{3}{|c|}{ Extended Specification (Figs. 2 and 3) } \\
\hline & \multicolumn{2}{|c|}{ Log Hourly Wage } & \multirow{2}{*}{$\begin{array}{l}\text { Firm } \\
\text { Wage } \\
\text { Effect } \\
\text { (3) }\end{array}$} & \multicolumn{2}{|c|}{ Log Hourly Wage } & \multirow{2}{*}{$\begin{array}{c}\text { Firm } \\
\text { Wage } \\
\text { Effect } \\
\\
\text { (6) }\end{array}$} \\
\hline & $\begin{array}{l}\text { Without } \\
\text { Firm Fixed } \\
\text { Effects } \\
(1)\end{array}$ & $\begin{array}{l}\text { With Firm } \\
\text { Fixed } \\
\text { Effects } \\
(2)\end{array}$ & & $\begin{array}{l}\text { Without } \\
\text { Firm Fixed } \\
\text { Effects } \\
(4)\end{array}$ & $\begin{array}{l}\text { With Firm } \\
\text { Fixed } \\
\text { Effects } \\
(5)\end{array}$ & \\
\hline $\begin{array}{l}\text { Low educ*Years } \\
\text { since entry }\end{array}$ & $\begin{array}{c}0.015 \\
(0.000)\end{array}$ & $\begin{array}{c}0.012 \\
(0.000)\end{array}$ & $\begin{array}{c}0.003 \\
(0.000)\end{array}$ & $\begin{array}{c}0.012 \\
(0.000)\end{array}$ & $\begin{array}{c}0.010 \\
(0.000)\end{array}$ & $\begin{array}{c}0.002 \\
(0.000)\end{array}$ \\
\hline $\begin{array}{l}\text { Low educ*Years } \\
\text { since entry }{ }^{2} / 100\end{array}$ & $\begin{array}{l}-0.028 \\
(0.001)\end{array}$ & $\begin{array}{l}-0.025 \\
(0.001)\end{array}$ & $\begin{array}{l}-0.003 \\
(0.001)\end{array}$ & $\begin{array}{l}-0.024 \\
(0.001)\end{array}$ & $\begin{array}{l}-0.020 \\
(0.001)\end{array}$ & $\begin{array}{l}-0.005 \\
(0.001)\end{array}$ \\
\hline $\begin{array}{l}\text { Low educ*Years } \\
\text { since entry } 3 / 10,000\end{array}$ & $\begin{array}{l}-0.004 \\
(0.002)\end{array}$ & $\begin{array}{c}0.004 \\
(0.002)\end{array}$ & $\begin{array}{l}-0.009 \\
(0.002)\end{array}$ & $\begin{array}{l}-0.005 \\
(0.003)\end{array}$ & $\begin{array}{c}0.002 \\
(0.002)\end{array}$ & $\begin{array}{l}-0.006 \\
(0.002)\end{array}$ \\
\hline Medium educ & $\begin{array}{l}-0.043 \\
(0.001)\end{array}$ & $\begin{array}{l}-0.068 \\
(0.001)\end{array}$ & $\begin{array}{c}0.025 \\
(0.001)\end{array}$ & $\begin{array}{l}-0.054 \\
(0.001)\end{array}$ & $\begin{array}{l}-0.080 \\
(0.001)\end{array}$ & $\begin{array}{c}0.021 \\
(0.001)\end{array}$ \\
\hline $\begin{array}{l}\text { Medium educ*Years } \\
\text { since entry }\end{array}$ & $\begin{array}{c}0.020 \\
(0.000)\end{array}$ & $\begin{array}{c}0.016 \\
(0.000)\end{array}$ & $\begin{array}{c}0.004 \\
(0.000)\end{array}$ & $\begin{array}{c}0.017 \\
(0.000)\end{array}$ & $\begin{array}{c}0.013 \\
(0.000)\end{array}$ & $\begin{array}{c}(.001) \\
0.003 \\
(0.000)\end{array}$ \\
\hline $\begin{array}{l}\text { Medium educ*Years } \\
\text { since entry }{ }^{2} / 100\end{array}$ & $\begin{array}{l}-0.048 \\
(0.001)\end{array}$ & $\begin{array}{l}-0.037 \\
(0.001)\end{array}$ & $\begin{array}{l}-0.010 \\
(0.001)\end{array}$ & $\begin{array}{l}-0.034 \\
(0.001)\end{array}$ & $\begin{array}{l}-0.025 \\
(0.001)\end{array}$ & $\begin{array}{l}-0.009 \\
(0.001)\end{array}$ \\
\hline $\begin{array}{l}\text { Medium educ*Years } \\
\text { since entry }{ }^{3} / 10,000\end{array}$ & $\begin{array}{c}0.033 \\
(0.002)\end{array}$ & $\begin{array}{c}0.025 \\
(0.002)\end{array}$ & $\begin{array}{c}0.008 \\
(0.002)\end{array}$ & $\begin{array}{c}0.011 \\
(0.003)\end{array}$ & $\begin{array}{l}0.008 \\
(0.002)\end{array}$ & $\begin{array}{c}0.003 \\
(0.002)\end{array}$ \\
\hline High educ & $\begin{array}{l}-0.057 \\
(0.002)\end{array}$ & $\begin{array}{l}-0.121 \\
(0.001)\end{array}$ & $\begin{array}{c}0.064 \\
(0.001)\end{array}$ & $\begin{array}{l}-0.090 \\
(0.002)\end{array}$ & $\begin{array}{l}-0.129 \\
(0.001)\end{array}$ & $\begin{array}{c}(0.062 \\
(0.001)\end{array}$ \\
\hline $\begin{array}{l}\text { High educ*Years } \\
\text { since entry }\end{array}$ & $\begin{array}{c}0.032 \\
(0.000)\end{array}$ & $\begin{array}{l}0.027 \\
(0.000)\end{array}$ & $\begin{array}{c}0.005 \\
(0.000)\end{array}$ & $\begin{array}{l}0.027 \\
(0.000)\end{array}$ & $\begin{array}{l}0.025 \\
(0.000)\end{array}$ & $\begin{array}{c}0.004 \\
(0.000)\end{array}$ \\
\hline $\begin{array}{l}\text { High educ*Years } \\
\text { since entry }{ }^{2} / 100\end{array}$ & $\begin{array}{l}-0.145 \\
(0.001)\end{array}$ & $\begin{array}{l}-0.085 \\
(0.001)\end{array}$ & $\begin{array}{l}-0.060 \\
(0.001)\end{array}$ & $\begin{array}{l}-0.123 \\
(0.001)\end{array}$ & $\begin{array}{l}-0.076 \\
(0.001)\end{array}$ & $\begin{array}{l}-0.056 \\
(0.001)\end{array}$ \\
\hline $\begin{array}{l}\text { High educ*Years } \\
\text { since entry }{ }^{3} / 10,000\end{array}$ & $\begin{array}{l}0.204 \\
(0.003)\end{array}$ & $\begin{array}{c}0.093 \\
(0.002)\end{array}$ & $\begin{array}{c}0.111 \\
(0.002)\end{array}$ & $\begin{array}{c}0.173 \\
(0.003)\end{array}$ & $\begin{array}{c}0.084 \\
(0.002)\end{array}$ & $\begin{array}{c}0.102 \\
(0.002)\end{array}$ \\
\hline Immigrant*Low educ & $\begin{array}{l}-0.112 \\
(0.008)\end{array}$ & $\begin{array}{l}-0.072 \\
(0.007)\end{array}$ & $\begin{array}{l}-0.039 \\
(0.005)\end{array}$ & $\begin{array}{l}-0.076 \\
(0.008)\end{array}$ & $\begin{array}{l}-0.039 \\
(0.007)\end{array}$ & $\begin{array}{l}-0.039 \\
(0.005)\end{array}$ \\
\hline $\begin{array}{l}\text { Imm*Low educ*Years } \\
\text { since entry }\end{array}$ & $\begin{array}{c}0.003 \\
(0.002)\end{array}$ & $\begin{array}{c}0.004 \\
(0.001)\end{array}$ & $\begin{array}{l}-0.001 \\
(0.001)\end{array}$ & $\begin{array}{l}-0.002 \\
(0.002)\end{array}$ & $\begin{array}{c}0.001 \\
(0.002)\end{array}$ & $\begin{array}{l}-0.001 \\
(0.001)\end{array}$ \\
\hline $\begin{array}{l}\text { Imm*Low educ*Years } \\
\text { since entry } / 100\end{array}$ & $\begin{array}{l}-0.062 \\
(0.011)\end{array}$ & $\begin{array}{l}-0.037 \\
(0.009)\end{array}$ & $\begin{array}{l}-0.025 \\
(0.007)\end{array}$ & $\begin{array}{l}-0.038 \\
(0.012)\end{array}$ & $\begin{array}{l}-0.024 \\
(0.010)\end{array}$ & $\begin{array}{l}-0.019 \\
(0.008)\end{array}$ \\
\hline $\begin{array}{l}\text { Imm*Low educ*Years } \\
\text { since entry } / 10,000\end{array}$ & $\begin{array}{c}0.130 \\
(0.021)\end{array}$ & $\begin{array}{c}0.067 \\
(0.017)\end{array}$ & $\begin{array}{c}0.063 \\
(0.014)\end{array}$ & $\begin{array}{c}0.098 \\
(0.022)\end{array}$ & $\begin{array}{c}0.049 \\
(0.019)\end{array}$ & $\begin{array}{c}0.053 \\
(0.015)\end{array}$ \\
\hline Imm*Medium educ & $\begin{array}{l}-0.208 \\
(0.010)\end{array}$ & $\begin{array}{l}-0.134 \\
(0.008)\end{array}$ & $\begin{array}{l}-0.074 \\
(0.006)\end{array}$ & $\begin{array}{l}-0.170 \\
(0.010)\end{array}$ & $\begin{array}{l}-0.100 \\
(0.008)\end{array}$ & $\begin{array}{l}-0.065 \\
(0.007)\end{array}$ \\
\hline $\begin{array}{l}\text { Imm*Med educ*Years } \\
\text { since entry }\end{array}$ & $\begin{array}{l}-0.005 \\
(0.002)\end{array}$ & $\begin{array}{c}0.002 \\
(0.002)\end{array}$ & $\begin{array}{l}-0.006 \\
(0.001)\end{array}$ & $\begin{array}{l}-0.007 \\
(0.002)\end{array}$ & $\begin{array}{c}0.001 \\
(0.002)\end{array}$ & $\begin{array}{l}-0.006 \\
(0.001)\end{array}$ \\
\hline $\begin{array}{l}\text { Imm*Med educ*Years } \\
\text { since entry }{ }^{2} / 100\end{array}$ & $\begin{array}{l}-0.012 \\
(0.014)\end{array}$ & $\begin{array}{l}-0.030 \\
(0.011)\end{array}$ & $\begin{array}{c}0.017 \\
(0.008)\end{array}$ & $\begin{array}{l}-0.006 \\
(0.015)\end{array}$ & $\begin{array}{l}-0.030 \\
(0.011)\end{array}$ & $\begin{array}{c}0.012 \\
(0.009)\end{array}$ \\
\hline $\begin{array}{l}\text { Imm*Med educ*Years } \\
\text { since entry } / 10,000\end{array}$ & $\begin{array}{l}0.050 \\
(0.027)\end{array}$ & $\begin{array}{c}0.071 \\
(0.021)\end{array}$ & $\begin{array}{l}-0.020 \\
(0.015)\end{array}$ & $\begin{array}{c}0.052 \\
(0.029)\end{array}$ & $\begin{array}{l}0.075 \\
(0.022)\end{array}$ & $\begin{array}{l}-0.006 \\
(0.016)\end{array}$ \\
\hline Imm*High educ & $\begin{array}{l}-0.331 \\
(0.015)\end{array}$ & $\begin{array}{l}-0.193 \\
(0.012)\end{array}$ & $\begin{array}{l}-0.138 \\
(0.009)\end{array}$ & $\begin{array}{l}-0.258 \\
(0.015)\end{array}$ & $\begin{array}{l}-0.138 \\
(0.013)\end{array}$ & $\begin{array}{l}-0.136 \\
(0.010)\end{array}$ \\
\hline
\end{tabular}




\begin{tabular}{|c|c|c|c|c|c|c|}
\hline $\begin{array}{l}\text { Imm*High educ*Years } \\
\text { since entry }\end{array}$ & $\begin{array}{l}-0.009 \\
(0.003)\end{array}$ & $\begin{array}{l}-0.005 \\
(0.002)\end{array}$ & $\begin{array}{l}-0.004 \\
(0.002)\end{array}$ & $\begin{array}{l}-0.007 \\
(0.003)\end{array}$ & $\begin{array}{l}-0.004 \\
(0.002)\end{array}$ & $\begin{array}{l}-0.001 \\
(0.002)\end{array}$ \\
\hline Imm*High educ*Years & 0.052 & 0.015 & 0.037 & 0.036 & 0.004 & 0.023 \\
\hline since entry ${ }^{2} / 100$ & $(0.018)$ & $(0.016)$ & $(0.011)$ & $(0.019)$ & $(0.017)$ & $(0.012)$ \\
\hline Imm*High educ*Years & -0.064 & 0.009 & -0.073 & -0.029 & 0.036 & -0.048 \\
\hline since entry ${ }^{3} / 10,000$ & $(0.036)$ & $(0.032)$ & $(0.023)$ & $(0.038)$ & $(0.033)$ & $(0.024)$ \\
\hline Educ missing (imm) & -0.055 & -0.030 & -0.025 & -0.015 & 0.009 & -0.026 \\
\hline & $(0.008)$ & $(0.006)$ & $(0.005)$ & $(0.009)$ & $(0.007)$ & $(0.006)$ \\
\hline Educ missing $*$ Years & 0.014 & 0.012 & 0.002 & 0.012 & 0.010 & 0.002 \\
\hline since entry & $(0.002)$ & $(0.002)$ & $(0.002)$ & $(0.003)$ & $(0.002)$ & $(0.002)$ \\
\hline Educ missing*Years & -0.072 & -0.024 & -0.048 & -0.064 & -0.013 & -0.050 \\
\hline since entry ${ }^{2} / 100$ & $(0.023)$ & $(0.018)$ & $(0.014)$ & $(0.024)$ & $(0.019)$ & $(0.015)$ \\
\hline Educ missing*Years & 0.112 & -0.014 & 0.127 & 0.107 & -0.025 & 0.128 \\
\hline since entry $/ 10,000$ & $(0.054)$ & $(0.043)$ & $(0.033)$ & $(0.057)$ & $(0.046)$ & $(0.035)$ \\
\hline Low educ*Age & 0.001 & 0.001 & -0.000 & 0.000 & 0.001 & -0.000 \\
\hline at entry & $(0.000)$ & $(0.000)$ & $(0.000)$ & $(0.000)$ & $(0.000)$ & $(0.000)$ \\
\hline Low educ*Age & 0.000 & 0.002 & -0.002 & 0.002 & 0.003 & -0.002 \\
\hline at entry ${ }^{2} / 100$ & $(0.004)$ & $(0.003)$ & $(0.003)$ & $(0.004)$ & $(0.003)$ & $(0.003)$ \\
\hline Low educ*Age & -0.005 & -0.006 & 0.002 & -0.005 & -0.007 & 0.002 \\
\hline at entry $3 / 10,000$ & $(0.019)$ & $(0.017)$ & $(0.012)$ & $(0.019)$ & $(0.017)$ & $(0.013)$ \\
\hline Medium educ*Age & 0.002 & 0.001 & 0.000 & 0.001 & 0.001 & 0.000 \\
\hline at entry & $(0.000)$ & $(0.000)$ & $(0.000)$ & $(0.000)$ & $(0.000)$ & $(0.000)$ \\
\hline Medium educ*Age & 0.001 & -0.004 & 0.005 & 0.004 & -0.001 & 0.006 \\
\hline at entry ${ }^{2} / 100$ & $(0.006)$ & $(0.005)$ & $(0.004)$ & $(0.006)$ & $(0.005)$ & $(0.004)$ \\
\hline Medium educ*Age & -0.039 & -0.001 & -0.038 & -0.044 & -0.012 & -0.035 \\
\hline at entry ${ }^{3} / 10,000$ & $(0.025)$ & $(0.019)$ & $(0.017)$ & $(0.025)$ & $(0.020)$ & $(0.017)$ \\
\hline High educ*Age & 0.002 & 0.006 & -0.004 & 0.001 & 0.005 & -0.004 \\
\hline at entry & $(0.001)$ & $(0.000)$ & $(0.000)$ & $(0.001)$ & $(0.000)$ & $(0.000)$ \\
\hline High educ*Age & 0.016 & 0.021 & -0.005 & 0.010 & 0.020 & -0.008 \\
\hline at entry ${ }^{2} / 100$ & $(0.010)$ & $(0.009)$ & $(0.007)$ & $(0.010)$ & $(0.009)$ & $(0.007)$ \\
\hline High educ*Age & -0.038 & -0.087 & 0.049 & -0.002 & -0.069 & 0.061 \\
\hline at entry ${ }^{3} / 10,000$ & $(0.044)$ & $(0.040)$ & $(0.027)$ & $(0.045)$ & $(0.042)$ & $(0.027)$ \\
\hline Educ missing*Age & 0.005 & 0.004 & 0.001 & 0.005 & 0.005 & 0.001 \\
\hline at entry & $(0.000)$ & $(0.000)$ & $(0.000)$ & $(0.000)$ & $(0.000)$ & $(0.000)$ \\
\hline Educ missing*Age & -0.022 & -0.006 & -0.016 & -0.022 & -0.007 & -0.015 \\
\hline at entry ${ }^{2} / 100$ & $(0.007)$ & $(0.005)$ & $(0.005)$ & $(0.008)$ & $(0.006)$ & $(0.005)$ \\
\hline Educ missing*Age & 0.096 & 0.042 & 0.055 & 0.099 & 0.040 & 0.059 \\
\hline at entry ${ }^{3} / 10,000$ & $(0.031)$ & $(0.022)$ & $(0.019)$ & $(0.035)$ & $(0.024)$ & $(0.021)$ \\
\hline Years of schooling & 0.052 & 0.047 & 0.005 & 0.053 & 0.048 & 0.005 \\
\hline & $(0.000)$ & $(0.000)$ & $(0.000)$ & $(0.000)$ & $(0.000)$ & $(0.000)$ \\
\hline Immigrant*Years of & 0.011 & 0.004 & 0.007 & 0.009 & 0.003 & 0.007 \\
\hline schooling & $(0.001)$ & $(0.001)$ & $(0.001)$ & $(0.001)$ & $(0.001)$ & $(0.001)$ \\
\hline Arrived before 1966 & 0.209 & 0.090 & 0.120 & 0.194 & 0.088 & 0.113 \\
\hline & $(0.025)$ & $(0.021)$ & $(0.016)$ & $(0.025)$ & $(0.021)$ & $(0.017)$ \\
\hline Arrived 1966-70 & 0.166 & 0.047 & 0.120 & 0.146 & 0.035 & 0.116 \\
\hline & $(0.014)$ & $(0.011)$ & $(0.011)$ & $(0.014)$ & $(0.011)$ & $(0.011)$ \\
\hline Arrived 1971-75 & 0.086 & -0.008 & 0.095 & 0.072 & -0.015 & 0.091 \\
\hline & $(0.010)$ & $(0.007)$ & $(0.007)$ & $(0.010)$ & $(0.007)$ & $(0.007)$ \\
\hline Arrived 1976-80 & 0.075 & -0.004 & 0.079 & 0.063 & -0.010 & 0.075 \\
\hline & $(0.007)$ & $(0.006)$ & $(0.005)$ & $(0.007)$ & $(0.006)$ & $(0.005)$ \\
\hline Arrived 1981-85 & 0.036 & -0.014 & 0.050 & 0.031 & -0.017 & 0.048 \\
\hline & $(0.005)$ & $(0.004)$ & $(0.004)$ & $(0.005)$ & $(0.004)$ & $(0.004)$ \\
\hline Arrived 1986-90 & -0.023 & -0.027 & 0.005 & -0.020 & -0.027 & 0.005 \\
\hline & $(0.003)$ & $(0.003)$ & $(0.002)$ & $(0.003)$ & $(0.003)$ & $(0.002)$ \\
\hline Arrived 1996-2000 & -0.033 & -0.012 & -0.021 & -0.039 & -0.019 & -0.020 \\
\hline & $(0.004)$ & $(0.003)$ & $(0.002)$ & $(0.004)$ & $(0.003)$ & $(0.002)$ \\
\hline
\end{tabular}




\begin{tabular}{|c|c|c|c|c|c|c|}
\hline Arrived 2001-05 & $\begin{array}{c}-0.046 \\
(0.005)\end{array}$ & $\begin{array}{c}-0.005 \\
(0.004)\end{array}$ & $\begin{array}{c}-0.042 \\
(0.003)\end{array}$ & $\begin{array}{c}-0.053 \\
(0.005)\end{array}$ & $\begin{array}{c}-0.014 \\
(0.004)\end{array}$ & $\begin{array}{c}-0.040 \\
(0.004)\end{array}$ \\
\hline \multirow[t]{2}{*}{ Native entry before 1966} & -0.010 & 0.002 & -0.013 & -0.013 & -0.006 & -0.007 \\
\hline & $(0.003)$ & $(0.003)$ & $(0.002)$ & $(0.004)$ & $(0.003)$ & $(0.003)$ \\
\hline \multirow[t]{2}{*}{ Native entry $1966-70$} & 0.000 & 0.010 & -0.010 & -0.001 & 0.004 & -0.005 \\
\hline & $(0.003)$ & $(0.002)$ & $(0.002)$ & $(0.003)$ & $(0.002)$ & $(0.002)$ \\
\hline \multirow[t]{2}{*}{ Native entry $1971-75$} & -0.005 & 0.009 & -0.014 & -0.006 & 0.005 & -0.011 \\
\hline & $(0.002)$ & $(0.002)$ & $(0.002)$ & $(0.003)$ & $(0.002)$ & $(0.002)$ \\
\hline \multirow[t]{2}{*}{ Native entry $1976-80$} & 0.004 & 0.013 & -0.009 & 0.004 & 0.011 & -0.007 \\
\hline & $(0.002)$ & $(0.001)$ & $(0.001)$ & $(0.002)$ & $(0.002)$ & $(0.001)$ \\
\hline \multirow[t]{2}{*}{ Native entry $1981-85$} & 0.008 & 0.014 & -0.006 & 0.007 & 0.013 & -0.005 \\
\hline & $(0.001)$ & $(0.001)$ & $(0.001)$ & $(0.001)$ & $(0.001)$ & $(0.001)$ \\
\hline \multirow[t]{2}{*}{ Native entry $1986-90$} & 0.003 & 0.009 & -0.006 & 0.002 & 0.008 & -0.006 \\
\hline & $(0.001)$ & $(0.001)$ & $(0.001)$ & $(0.001)$ & $(0.001)$ & $(0.001)$ \\
\hline \multirow[t]{2}{*}{ Native entry $1996-2000$} & -0.023 & -0.017 & -0.007 & -0.023 & -0.016 & -0.007 \\
\hline & $(0.001)$ & $(0.001)$ & $(0.001)$ & $(0.001)$ & $(0.001)$ & $(0.001)$ \\
\hline \multirow[t]{2}{*}{ Native entry 2001-05 } & -0.069 & -0.051 & -0.019 & -0.065 & -0.052 & -0.014 \\
\hline & $(0.002)$ & $(0.001)$ & $(0.001)$ & $(0.002)$ & $(0.001)$ & $(0.001)$ \\
\hline \multirow[t]{2}{*}{ Year 1998} & 0.072 & 0.067 & & 0.073 & 0.068 & \\
\hline & $(0.001)$ & $(0.001)$ & & $(0.001)$ & $(0.001)$ & \\
\hline \multirow[t]{2}{*}{ Year 1999} & 0.107 & 0.099 & & 0.109 & 0.101 & \\
\hline & $(0.001)$ & $(0.001)$ & & $(0.001)$ & $(0.001)$ & \\
\hline \multirow[t]{2}{*}{ Year 2000} & 0.152 & 0.144 & & 0.155 & 0.147 & \\
\hline & $(0.001)$ & $(0.001)$ & & $(0.001)$ & $(0.001)$ & \\
\hline \multirow[t]{2}{*}{ Year 2001} & 0.194 & 0.188 & & 0.198 & 0.190 & \\
\hline & $(0.001)$ & $(0.001)$ & & $(0.001)$ & $(0.001)$ & \\
\hline \multirow[t]{2}{*}{ Year 2002} & 0.249 & 0.240 & & 0.256 & 0.242 & \\
\hline & $(0.001)$ & $(0.001)$ & & $(0.001)$ & $(0.001)$ & \\
\hline \multirow[t]{2}{*}{ Year 2003} & 0.280 & 0.266 & & 0.286 & 0.268 & \\
\hline & $(0.001)$ & $(0.001)$ & & $(0.001)$ & $(0.001)$ & \\
\hline \multirow[t]{2}{*}{ Year 2004} & 0.312 & 0.298 & & 0.320 & 0.299 & \\
\hline & $(0.001)$ & $(0.001)$ & & $(0.001)$ & $(0.001)$ & \\
\hline \multirow{2}{*}{ Year 2005} & 0.343 & 0.332 & & 0.351 & 0.332 & \\
\hline & $(0.001)$ & $(0.001)$ & & $(0.001)$ & $(0.001)$ & \\
\hline \multirow[t]{2}{*}{ Year 2006} & 0.384 & 0.371 & & 0.393 & 0.372 & \\
\hline & $(0.001)$ & $(0.001)$ & & $(0.001)$ & $(0.001)$ & \\
\hline Low educ* $\ln ($ local & -0.015 & -0.008 & -0.006 & -0.014 & -0.008 & -0.006 \\
\hline unemployment) & $(0.001)$ & $(0.001)$ & $(0.001)$ & $(0.001)$ & $(0.001)$ & $(0.001)$ \\
\hline Medium educ* $\ln ($ local & -0.020 & -0.014 & -0.005 & -0.019 & -0.014 & -0.004 \\
\hline unemployment) & $(0.001)$ & $(0.001)$ & $(0.001)$ & $(0.001)$ & $(0.001)$ & $(0.001)$ \\
\hline High educ* $\ln ($ local & -0.012 & -0.005 & -0.006 & -0.009 & -0.004 & -0.005 \\
\hline unemployment) & $(0.001)$ & $(0.001)$ & $(0.001)$ & $(0.001)$ & $(0.001)$ & $(0.001)$ \\
\hline Imm*Low educ* $\ln ($ local & 0.005 & 0.012 & -0.006 & 0.002 & 0.007 & -0.006 \\
\hline unemployment) & $(0.004)$ & $(0.003)$ & $(0.003)$ & $(0.004)$ & $(0.003)$ & $(0.003)$ \\
\hline Imm*Med educ* $\ln ($ local & 0.005 & 0.009 & -0.004 & 0.002 & 0.007 & -0.006 \\
\hline unemployment) & $(0.004)$ & $(0.003)$ & $(0.003)$ & $(0.004)$ & $(0.003)$ & $(0.003)$ \\
\hline Imm*High educ* $\ln ($ local & -0.003 & 0.003 & -0.006 & -0.011 & -0.001 & -0.009 \\
\hline unemployment) & $(0.007)$ & $(0.005)$ & $(0.005)$ & $(0.007)$ & $(0.005)$ & $(0.005)$ \\
\hline Educ missing* $\ln ($ local & 0.004 & 0.005 & -0.000 & 0.003 & 0.004 & 0.001 \\
\hline unemployment) & $(0.006)$ & $(0.004)$ & $(0.004)$ & $(0.006)$ & $(0.005)$ & $(0.004)$ \\
\hline Trend & & & 0.001 & & & 0.002 \\
\hline & & & $(0.000)$ & & & $(0.000)$ \\
\hline Low educ* & & & & 0.014 & 0.012 & \\
\hline Seniority & & & & $(0.000)$ & $(0.000)$ & \\
\hline Low educ* & & & & -0.070 & -0.061 & \\
\hline Seniority $^{2} / 100$ & & & & $(0.002)$ & $(0.001)$ & \\
\hline
\end{tabular}




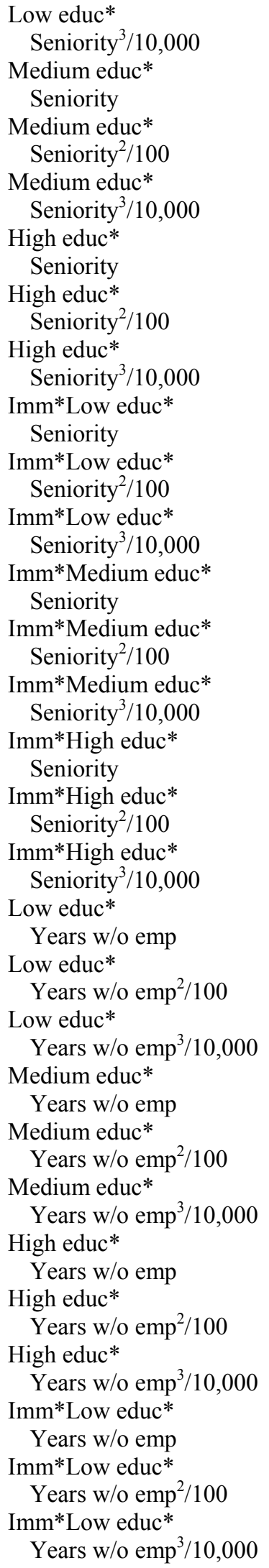

\begin{tabular}{|c|c|c|}
\hline 0.108 & 0.093 & \\
\hline$(0.003)$ & $(0.003)$ & \\
\hline 0.015 & 0.016 & \\
\hline$(0.000)$ & $(0.000)$ & \\
\hline-0.098 & -0.097 & \\
\hline$(0.002)$ & $(0.002)$ & \\
\hline 0.168 & 0.164 & \\
\hline$(0.005)$ & $(0.004)$ & \\
\hline 0.030 & 0.016 & \\
\hline$(0.000)$ & $(0.000)$ & \\
\hline-0.208 & -0.105 & \\
\hline$(0.003)$ & $(0.002)$ & \\
\hline 0.403 & 0.196 & \\
\hline$(0.007)$ & $(0.005)$ & \\
\hline 0.004 & 0.000 & \\
\hline$(0.001)$ & $(0.001)$ & \\
\hline-0.027 & -0.016 & \\
\hline$(0.013)$ & (0.009) & \\
\hline 0.027 & 0.033 & \\
\hline$(0.031)$ & $(0.022)$ & \\
\hline 0.008 & -0.001 & \\
\hline$(0.002)$ & $(0.001)$ & \\
\hline-0.072 & -0.004 & \\
\hline (0.019) & $(0.015)$ & \\
\hline 0.163 & 0.013 & \\
\hline$(0.051)$ & $(0.041)$ & \\
\hline-0.008 & -0.011 & \\
\hline$(0.003)$ & $(0.002)$ & \\
\hline 0.038 & 0.090 & \\
\hline$(0.032)$ & $(0.024)$ & \\
\hline-0.053 & -0.250 & \\
\hline$(0.094)$ & $(0.070)$ & \\
\hline-0.003 & -0.002 & -0.001 \\
\hline$(0.000)$ & $(0.000)$ & $(0.000)$ \\
\hline 0.026 & 0.016 & 0.011 \\
\hline$(0.005)$ & $(0.004)$ & $(0.003)$ \\
\hline-0.049 & -0.037 & -0.014 \\
\hline$(0.011)$ & $(0.009)$ & $(0.008)$ \\
\hline 0.005 & -0.000 & 0.006 \\
\hline$(0.001)$ & $(0.000)$ & $(0.000)$ \\
\hline-0.046 & 0.003 & -0.054 \\
\hline$(0.008)$ & $(0.006)$ & $(0.005)$ \\
\hline 0.092 & -0.017 & 0.117 \\
\hline$(0.022)$ & $(0.017)$ & $(0.014)$ \\
\hline 0.003 & -0.006 & 0.008 \\
\hline$(0.001)$ & $(0.000)$ & $(0.001)$ \\
\hline-0.071 & 0.035 & -0.101 \\
\hline$(0.011)$ & $(0.007)$ & $(0.008)$ \\
\hline 0.221 & -0.046 & 0.257 \\
\hline$(0.031)$ & $(0.021)$ & $(0.024)$ \\
\hline 0.004 & -0.002 & 0.005 \\
\hline$(0.002)$ & $(0.001)$ & $(0.001)$ \\
\hline-0.063 & 0.009 & -0.065 \\
\hline$(0.020)$ & $(0.016)$ & $(0.015)$ \\
\hline 0.180 & 0.006 & 0.160 \\
\hline$(0.053)$ & $(0.044)$ & $(0.043)$ \\
\hline
\end{tabular}


Imm*Medium educ*

Years w/o emp

Imm*Medium educ*

Years w/o emp ${ }^{2} / 100$

Imm*Medium educ*

Years w/o emp $3 / 10,000$

Imm*High educ*

Years w/o emp

Imm*High educ*

Years w/o emp ${ }^{2} / 100$

Imm*High educ*

Years w/o emp $3 / 10,000$

Constant

\begin{tabular}{|c|c|c|c|c|c|}
\hline & & & $\begin{array}{l}-0.017 \\
(0.002)\end{array}$ & $\begin{array}{l}-0.008 \\
(0.002)\end{array}$ & $\begin{array}{c}-0.010 \\
(0.002)\end{array}$ \\
\hline & & & 0.149 & 0.060 & 0.102 \\
\hline & & & $(0.032)$ & $(0.024)$ & $(0.027)$ \\
\hline & & & -0.309 & -0.082 & -0.257 \\
\hline & & & $(0.096)$ & $(0.075)$ & $(0.096)$ \\
\hline & & & -0.028 & -0.014 & -0.016 \\
\hline & & & $(0.003)$ & $(0.002)$ & $(0.002)$ \\
\hline & & & 0.325 & 0.143 & 0.201 \\
\hline & & & $(0.041)$ & $(0.030)$ & $(0.031)$ \\
\hline & & & -0.821 & -0.354 & -0.505 \\
\hline & & & $(0.120)$ & $(0.085)$ & $(0.090)$ \\
\hline 4.586 & 4.638 & -0.049 & 4.558 & 4.613 & -0.049 \\
\hline$(0.001)$ & $(0.001)$ & $(0.001)$ & $(0.001)$ & $(0.001)$ & $(0.001)$ \\
\hline
\end{tabular}

Note: Standard errors are reported in parentheses. Sample sizes are 4,918,260 in columns (1)-(3) and 4,745,275 in columns (4)-(6). The model in column (2) includes 90,189 firm fixed effects and that in column (5) 88,884 firm fixed effects. Regressions are weighted using sampling weights for the firm. Constant terms are evaluated at median age at arrival $(26,27$, and 29 for the three education groups, respectively), compulsory schooling (10), entry cohort 1991-95, observation year 1997, and the sample mean of log local unemployment rate.

Table A2. Immigrant-native wage differential by years since migration, with controls for years of non-employment, seniority and native fixed firm effects.

\begin{tabular}{lccc}
\hline Years since entry: & $\begin{array}{c}\text { Low education } \\
(1)\end{array}$ & $\begin{array}{c}\text { Medium education } \\
(2)\end{array}$ & $\begin{array}{c}\text { High education } \\
(3)\end{array}$ \\
\hline 1 & -0.083 & -0.114 & -0.145 \\
& $(0.010)$ & $(0.010)$ & $(0.015)$ \\
5 & -0.081 & -0.108 & -0.144 \\
& $(0.007)$ & $(0.007)$ & $(0.009)$ \\
10 & -0.084 & -0.111 & -0.145 \\
& $(0.007)$ & $(0.007)$ & $(0.009)$ \\
15 & -0.090 & -0.112 & -0.144 \\
& $(0.008)$ & $(0.008)$ & $-0.009)$ \\
20 & -0.097 & -0.124 & $(0.010)$ \\
& $(0.010)$ & $(0.009)$ & -0.119 \\
& -0.101 & -0.123 & $(0.013)$ \\
\hline
\end{tabular}

